\title{
FT-IR Investigation of the Structural Changes of Sulcis and South Africa Coals under Progressive Heating in Vacuum: Correlation with Volatile Matter
}

\author{
Aldo D’Alessio, Anna Maria Raspolli-Galletti, Domenico Licursi, and Marco Martinelli \\ Dipartimento di Chimica e Chimica Industriale, Università di Pisa, Via Risorgimento 35, 56126 Pisa, Italy \\ Correspondence should be addressed to Aldo D’Alessio; aldo@dcci.unipi.it
}

Received 30 January 2013; Revised 27 May 2013; Accepted 31 May 2013

Academic Editor: Peter F. Nelson

Copyright (C) 2013 Aldo D’Alessio et al. This is an open access article distributed under the Creative Commons Attribution License, which permits unrestricted use, distribution, and reproduction in any medium, provided the original work is properly cited.

\begin{abstract}
The analysis of gas evolving during the pyrolysis of two very different rank coals was studied by using FT-IR spectroscopy. These coals, coming from Sulcis (Sardinia, Italy) and from South Africa, respectively, were subjected to progressive heating up to $800^{\circ} \mathrm{C}$ in vacuum. The thermal destruction of coal was followed by monitoring the production of gases in this range of temperature. The gases evolving in the heating from room temperature to $800^{\circ} \mathrm{C}$ were collected at intervals of $100^{\circ} \mathrm{C}$ and analysed by infrared spectroscopy. The relative pressures $P_{r(i)}=P_{(i)} / P_{\max (i)}(T)$ were plotted against temperature. These graphs clearly show the correlation among qualitative gas composition, temperature, and the maximum value of emissions, thus confirming FT-IR analysis as a powerful key for pyrolysis monitoring.
\end{abstract}

\section{Introduction}

Pyrolysis represents the first step in most solid fuel conversion processes, including combustion, gasification, and liquefaction, and has a significant influence on every subsequent stage for the recovery of valuable chemicals and energy [1]. Coal has been used for a long period both as fossil fuel and as raw material by the chemical industry. Currently, petroleum and natural gas represent the two main energy sources, but it is well-known that these supplies have no longer kept pace with the ever-increasing energy demand of many nations. As a result, an imperative need to rely on a well-known energy source such as coal is paramount. Unfortunately, impurities of coal such as sulphur and nitrogen derivatives are released into the atmosphere causing problems such as acid rains and smog. The unburnt mineral matter can also be released into the air as particulate. However, what concerns the most is $\mathrm{CO}_{2}$ emissions, which are believed to influence climate change. Due to the role that coal plays in the energy production, it would be worthwhile to reduce the negative effects of air pollution caused by $\mathrm{CO}_{x}$ and $\mathrm{NO}_{x}$ emissions by increasing the efficiency of coal conversion [2-4].
Coal pyrolysis is considered an effective way for its clean use because desulfurized char and tar can be obtained at the end of the reaction. Coal tar can be utilized as raw material for the industrial synthesis of dyes, plastics, synthetic fibres, fine chemicals, and cosmetic products, due to its good activity as a cosmetic biocide [5]. It is also a type of raw material from which phenols, naphthalenes, and anthracene can be extracted for the production of washing oil, cementitious agent and catalytically hydrogenated products to obtain gasoline, diesel oil, and so forth. Therefore, it is necessary to deepen the understanding of the pyrolysis process, by investigating both raw materials and the originated products, in order to optimize the reaction conditions.

The study of pyrolysis is also of interest for its possible application to innovative materials such as biomass. Both coal and biomass have complex structures containing a number of different constituents. These constituents show their inherent individual characteristics during thermal processes, and each one contributes to the apparent thermal characteristics of the feedstock. On the other hand, when coal and biomass are treated as blend in processes such as copyrolysis, cocombustion, or cogasification, some positive synergistic interactions 
may take place, leading to significant variations in the thermal reactivity of the resulting samples or in the physical or chemical properties of the products [6-8].

Coal thermal degradation generates gaseous, liquid, and solid products. The primary decomposition products which are initially formed probably decompose in turn, and the resulting fragments react further with each other and with the solid residue to form the observed tars, liquors, water vapors, gases, and char. Due to these secondary reactions, the decomposition products which are eventually observed may be far removed from the original coal structure, offering few clues to the chemical constitution of coal. In this context, pyrolysis of coal under reduced pressures has been used to minimize these secondary reactions [9-12].

Among the variables of processes which characterize the pyrolysis, temperature and time have the most remarkable effect on the structural changes ascribed to organic and inorganic parts of coals [13-15].

Coal undergoes many physical and chemical changes when gradually heated from ambient temperature to approximately $1000^{\circ} \mathrm{C}$ [16]. The temperature ranges for the various pyrolysis events significantly depend on the heating rate. At slow heating rate (about $5^{\circ} \mathrm{C} / \mathrm{s}$ ), the maximum devolatilization occurs at around $400^{\circ} \mathrm{C}$, whereas increasing the heating rate up to about $10^{\circ} \mathrm{C} / \mathrm{s}$, this maximum might not occur until $900^{\circ} \mathrm{C}$. This is a "conventional" pyrolysis and employs low heating rates and modest residence times (about 5-30 minutes) for the recovery of char. This technology is still widely used because it provides a clean feedstock of combustion/ gasification for electric power generation. On the other hand, "fast" pyrolysis employs, respectively, very high heating rates (up to $1000^{\circ} \mathrm{C} / \mathrm{s}$ ) and very short residence times $(0.5-5 \mathrm{~s}$ ), minimizing the formation of char and breaking the bonds of the molecular species, recovering mainly liquid and gaseous products [17].

Fourier Transform Infrared Spectroscopy (FT-IR) plays an important role in the elucidation of chemical structure of coal, chars, and gas evolving during oxidation and pyrolysis processes [18-21]. This research closely links to the application of FT-IR on the pyrolysis of new green materials such as biomass, since the chemical groups are similar and char is among the final products obtained. The chemical characterization of the evolved gas in the pyrolysis process by FT-IR spectroscopy is therefore an important tool for understanding the properties of these materials.

Many pyrolysis processes were extensively investigated [22], and the thermal decomposition of the functional groups present in the coals was widely studied by using infrared spectroscopy $[23,24]$.

Recently, many researchers have applied integrated techniques such as thermogravimetry (TG) and derivative thermogravimetry (DTG), differential scanning calorimetry (DSC), and Fourier Transform Infrared Spectroscopy (FT-IR) in order to study the pyrolysis of coal $[4,25,26]$.

Among all these studies, Carangelo et al. [27] and Solomon et al. [28] investigated hydrocarbons structure and the kinetics of gas evolution by using a TG/FT-IR technique to study the pyrolysis of coal, char, tar, and oil shale. They identified the individual gaseous species such as CO,
$\mathrm{CO}_{2}, \mathrm{H}_{2} \mathrm{O}, \mathrm{CH}_{4}, \mathrm{C}_{2} \mathrm{H}_{6}, \mathrm{C}_{2} \mathrm{H}_{4}, \mathrm{C}_{2} \mathrm{H}_{2}, \mathrm{C}_{3} \mathrm{H}_{8}$, benzene, heavy paraffins, heavy olefins, $\mathrm{HCN}, \mathrm{HCl}, \mathrm{NH}_{3}, \mathrm{SO}_{2}, \mathrm{CS}_{2}, \mathrm{COS}$, $\mathrm{CH}_{3} \mathrm{OH}, \mathrm{CH}_{3} \mathrm{COOH}$, and $\mathrm{CH}_{3} \mathrm{COCH}_{3}$. Pitkänen et al. [29] studied various fuels, such as coal, peat, wood chips, and bark with FT-IR spectrometry combined with TG. FT-IR spectra and TG curves indicated that the main evolved gases were $\mathrm{CO}_{2}$ and $\mathrm{H}_{2} \mathrm{O}$, while there were many minor gases, such as $\mathrm{CO}_{2}, \mathrm{CH}_{4}, \mathrm{C}_{2} \mathrm{H}_{6}, \mathrm{CH}_{3} \mathrm{OH}, \mathrm{CH}_{3} \mathrm{COOH}$, and $\mathrm{HCOOH}$.

Many chromatographic techniques were developed to study coals and coal-derived products. These included gas chromatography and liquid chromatography [30]. A flame ionization detector (FID) [31] was mostly used to detect coal compounds coming out from a chromatographic column. Also, gas chromatography coupled with mass spectrometry (GC-MS) was frequently used to study coals $[32,33]$. Finally, the development of analytical chemistry fostered the use of combined methods based on pyrolysis gas chromatography coupled with mass detection (Py-GC-MS) [31, 34].

However, among all these analytical techniques, infrared spectroscopy remains one of the most simple and effective ones to evaluate and monitor the pyrolysis products. In a previous study [35], we investigated the structural changes of two bituminous coals, a Sulcis and a South Africa one, by FT-IR spectroscopy under slowly heating temperature programmed mode, from 25 to $800^{\circ} \mathrm{C}$, under vacuum. In this research, the analysis of gas evolving during the pyrolysis of two different rank coals by using FT-IR spectroscopy was studied under the same heating conditions. The main aim of this work is to establish the correlation between the evolution of vapors and gases and the structural changes of the functional groups during the pyrolysis process.

\section{Materials and Methods}

Coal samples were ground with a ball mill for 15 minutes and subsequently sieved in order to obtain samples of average $70 \mu \mathrm{m}$ granulometric size.

Ultimate and proximate analysis of these two types of coal were performed by a Perkin-Elmer analyser mod. 240 and a Thermoanalyser Mettler TA 1, respectively.

In order to confirm the results of the IR analysis, the gas chromatography/mass spectrometry (GC-MS) analysis of some condensates was performed by using the gaschromatograph Hewlett-Packard HP 6890 equipped with a MSD HP 5973 detector and with a G.C. column Phenomenex Zebron with a $100 \%$ methyl polysiloxane stationary phase (column length $30 \mathrm{~m}$, inner diameter $0.25 \mathrm{~mm}$, and thickness of the stationary phase $0.25 \mu \mathrm{m}$ ). The transport gas was helium 5.5 and the flow was $1 \mathrm{~mL} / \mathrm{min}$. The temperature of the injection port was set at $250^{\circ} \mathrm{C}$, carrier pressure at $100 \mathrm{kPa}$, and split flow at $3.40 \mathrm{~ms}^{-1}$. The oven was heated at $30^{\circ} \mathrm{C}$ for $5 \mathrm{~min}$, and then the temperature was raised at $5^{\circ} \mathrm{C} / \mathrm{min}$ up to $250^{\circ} \mathrm{C}$.

The apparatus used in the pyrolysis experiments is shown in Figure 1.

One hundred grams of each sample were put in a quartz pipe of a temperature-controlled furnace. All the equipments were conditioned with a cycle of vacuum-nitrogen at room temperature. Subsequently, the apparatus was put under 


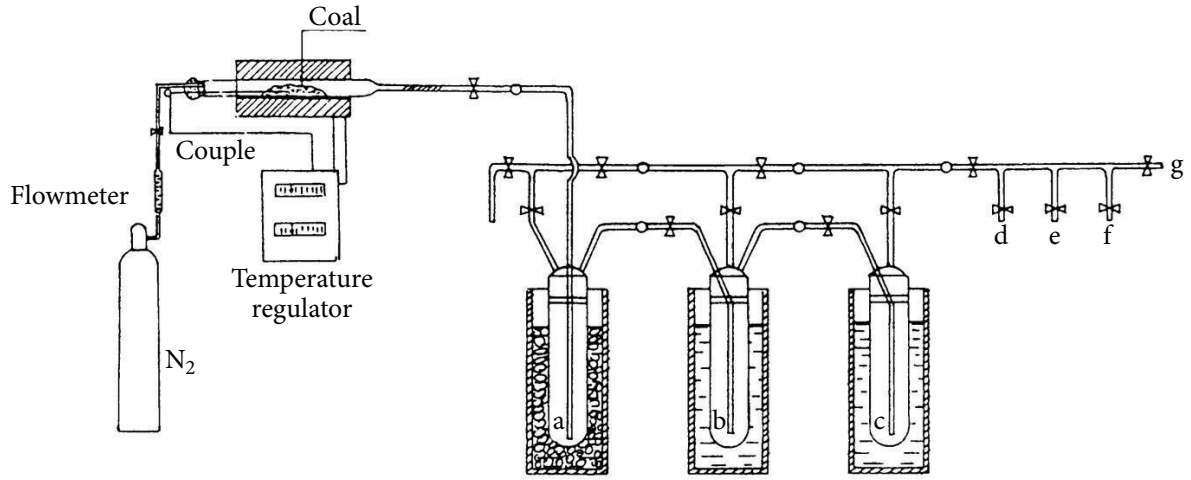

FIGURE 1: System used for heating coals up to $800^{\circ} \mathrm{C}$ : (a) cooling trap with water + salts at $-15^{\circ} \mathrm{C}$; (b) cooling trap with solid $\mathrm{CO}_{2}(\mathrm{~s})+$ acetone at $-77^{\circ} \mathrm{C}$; (c) cooling trap with liquid nitrogen at $-180^{\circ} \mathrm{C}$; (d), (e), (f), and (g) taps.

vacuum and the working temperature was set. The same procedure was repeated for all temperatures (from $100^{\circ} \mathrm{C}$ to $800^{\circ} \mathrm{C}$ ), performing the same thermal gradient for all experiments (nominal heating rate equal to $2^{\circ} \mathrm{C} / \mathrm{s}$ ) and maintaining the samples at these temperatures for a period of thirty minutes.

About the collection of the reaction products, the first fraction was collected in a first cooling trap with a water + salts bath at about $-15^{\circ} \mathrm{C}$ (trap a in Figure 1), and subsequently the other fractions were collected in the cooling traps with a solid $\mathrm{CO}_{2}+$ acetone bath at about $-77^{\circ} \mathrm{C}$ (trap b in Figure 1$)$ and with a liquid nitrogen bath at $-180^{\circ} \mathrm{C}$ (trap $\mathrm{c}$ in Figure 1), respectively. Finally, the noncondensable gases were collected from the last taps (taps d-g in Figure 1).

FT-IR spectra of the vapors and gases were recorded with a FT-IR Perkin-Elmer mod. 2000 spectrometer. One hundred scans of $1 \mathrm{~cm}^{-1}$ resolution were set, and the average signals obtained were stored on a magnetic disk for further analysis.

The quantitative analysis of the various gaseous components was carried out by means of infrared spectroscopy using a $1 \mathrm{~m}$ optical path gas cell with CsI windows. The gas cell was evacuated and the gas was introduced by means of the tap g of Figure 1. A suitable mercury manometer connected to the gas cell has allowed the introduction of a known quantity of gas and the measurement of its relative pressure at room temperature. In this way, direct correlations between absorbance and relative pressure of the individual components were obtained.

\section{Results and Discussion}

The Sulcis mines represent the only reserve of coal in Italy (Sardinia, Italy). Therefore, this coal was studied for its remarkable abundance. On the other hand, South Africa coal was considered in this work thanks to its well-known different chemical composition with respect to that of Sulcis coal. In addition, many experimental data are reported in the literature for these two types of coals, and now this study will further contribute to supplement our previous results [35].

In Table 1, data of ultimate and proximate analysis of these two types of coal are reported.

The data corresponding to the proximate analysis of the Sulcis coal show a higher amount of volatiles and ashes and
TABLE 1: Elemental and proximate analysis data of investigated coals ${ }^{*}$.

\begin{tabular}{lccccccccc}
\hline \multirow{3}{*}{ Coal } & \multicolumn{4}{c}{ Elemental analysis (wt\% d.b.) Proximate analysis (wt\%) } \\
& $\mathrm{C}$ & $\mathrm{H}$ & $\mathrm{N}$ & $\mathrm{S}$ & $\mathrm{O}$ & $\mathrm{M}$ & $\mathrm{C}_{\mathrm{f}}$ & $\mathrm{V}_{\mathrm{m}}$ & $\mathrm{A}$ \\
\hline Sulcis & 52.8 & 4.2 & 1.4 & 5.9 & 11.5 & 8.2 & 40.1 & 35.6 & 16.0 \\
$\begin{array}{l}\text { South } \\
\text { Africa }\end{array}$ & 66.5 & 3.6 & 1.7 & 0.6 & 8.6 & 2.5 & 47.8 & 23.3 & 16.5 \\
\hline
\end{tabular}

* As - received.

d.b.: on dry basis; $\mathrm{M}$ : moisture; $\mathrm{C}_{\mathrm{f}}$ : carbon Fixed; A: ashes; $\mathrm{V}_{\mathrm{m}}$ : volatile matter.

Oxygen content was calculated by difference. $\mathrm{O}=100-\mathrm{C}-\mathrm{H}-\mathrm{N}-\mathrm{S}-$ ash.

a lower quantity of fixed carbon. These data immediately evidence substantial differences of Sulcis coal with respect to the South Africa one. Furthermore, also ultimate data analysis shows that Sulcis coal is completely different from the South African one, in particular for carbon and sulphur content.

In a previous investigation on these coals [35], the related structural changes associated with the organic and inorganic parts were analyzed. In detail, the analysis of the low temperature ash (LTA) and the application of FT-IR subtraction technique for Sulcis coal revealed a high concentration of sulphates, carbonates, and pyrite, $\mathrm{SiO}_{2}$ and a lower concentration of clay minerals. In the FT-IR spectra of the South Africa coal, the absorption bands due to clay minerals (e.g., kaolinite, nacrite, dikite, etc.) can be observed. Spectral changes of the corresponding chars were mainly observed at high temperatures, when the decomposition of mineral matter occurs. On the other hand, at low temperatures, mineral matter was not still degraded, giving very intense bands adsorptions, due to its high extinction coefficient [35].

In the current research, gases evolving during pyrolysis of these two kinds of coal in the temperature range from 25 to $800^{\circ} \mathrm{C}$ at intervals of $100^{\circ} \mathrm{C}$ were analyzed by using the apparatus of Figure 1, by means of FT-IR spectroscopy. The IR spectra of liquid materials collected in the trap (a) revealed that they consist mainly of water and only a few traces of hydrocarbons. This liquid fraction was not further analyzed by gas chromatography, due to its low content of the organic components. 
The amounts of liquid materials (wt\%) collected in the cooling traps (a) and (b) in relation to the heating temperature for both coals are reported, respectively, in Figure 2(a) and in Figure 2(b).

Sulcis coal showed three maximum emissions at 100, 500 and $700^{\circ} \mathrm{C}$ (Figure 2(a)). The first, corresponding to $5.2 \mathrm{wt} \%$, was due almost exclusively to moisture, while the other two were constituted by hydration water associated with minerals, released at higher temperatures, and hydrocarbons.

On the other hand, the South African coal gave an appreciable amount of liquids in the cooling trap (a) only at higher values of temperature, over $500^{\circ} \mathrm{C}$ (Figure $2(\mathrm{a})$ ), while moisture was collected in the trap (b) at a heating temperature of $100^{\circ} \mathrm{C}$ (Figure $2(\mathrm{~b})$ ) in relation to the contemporary emission of ammonia, detected by infrared analysis, the presence of which lowers the temperature of liquefaction of the vapors [36]. This different behaviour of the South Africa coal may be due to the presence of two kinds of nitrogenous compounds, one of which is easily decomposable by heating at low temperature. This would suggest that in South Africa coal there are ammonium salts that develop ammonia by increasing temperature.

The pressure data obtained relatively to vapors and gases are plotted in Figures 3(a) and 3(b) as a function of temperature.

The pressure data were measured at room temperature by using a mercury manometer. The graph of Figure 3(a) shows that for Sulcis coal, a first type of products was evolved in the temperature range between 25 and $600^{\circ} \mathrm{C}$, with a maximum at about $400^{\circ} \mathrm{C}$, while from $600^{\circ} \mathrm{C}$ to about $800^{\circ} \mathrm{C}$, other components were produced, unlike the South Africa litanthrace, which, instead, presented a maximum at about $700^{\circ} \mathrm{C}$

The graph of Figure 3(b) shows a big quantitative difference among gas fractions which were collected from the two coals in the trap (c) cooled at $-180^{\circ} \mathrm{C}$. In particular, the pressure of the gaseous components was higher for Sulcis coal rather than the South African one.

The products obtained by heating at lower temperatures have a different distribution. The IR spectra of the condensates collected in the cooling trap (b), coming from the devolatilization of both coals at different temperatures, are shown in Figure 4.

Furthermore, the qualitative distribution of the pyrolysis products collected in trap (b) is reported in Table 2, on the basis of the intensities of their analytical infrared bands [37, 38], each reported in Table 3.

The global comparison between the IR spectra of Figure 4 reveals the presence of oxygenate compounds, mainly ketones and alcohols (acetone, methyl ethyl ketone, methanol, and ethanol), saturated $\left(\mathrm{C}_{3}-\mathrm{C}_{5}\right)$, unsaturated (olefins), and aromatic (benzene, toluene, and xylenes) hydrocarbons, and nitrogen derivatives (ammonia, hydrocyanic acid). Emission of oxygenates and hydrocarbons significantly begins at $300^{\circ} \mathrm{C}$ and increases up to about $600^{\circ} \mathrm{C}$ and then decreases. In particular, acetone and methyl ethyl ketone were identified on the basis of the stretching of the $\mathrm{C}=\mathrm{O}$ group at about $2000-1500 \mathrm{~cm}^{-1}$, as reported in Table 3. Aromatics were identified from the analytical bands at $1670-1430 \mathrm{~cm}^{-1}$ and at $1100-800 \mathrm{~cm}^{-1}$, due to the stretching and bending $\mathrm{C}=\mathrm{C}$ of ring, respectively (Table 3 ). Saturated hydrocarbons were identified from the analytical band at $3200-2800 \mathrm{~cm}^{-1}$, due to the stretching of $\mathrm{C}-\mathrm{H}$ bond (Table 3). Instead, the unsaturated ones were identified from the analytical band at about $3200-3000 \mathrm{~cm}^{-1}$ and at $1100-$ $800 \mathrm{~cm}^{-1}$, due to the stretching and bending (out of plane) of $\mathrm{H}-\mathrm{C}=\mathrm{C}$ bond, respectively (Table 3 ).

Nitrogen products (hydrocyanic acid and ammonia) were detected. In particular, at low wavenumbers (i.e., 750$650 \mathrm{~cm}^{-1}$ ), hydrocyanic acid showed absorption bands which suffered interference due to other components (Figure 4). Its recognition was possible only by considering the analytical band at $3312 \mathrm{~cm}^{-1}$, due to the stretching of $\mathrm{H}-\mathrm{C} \equiv \mathrm{N}$ bond, as reported in Table 3 .

As regards ammonia, it was recognized on the basis of the bands at $1250-680 \mathrm{~cm}^{-1}$, due to the bending (in plane and out of plane) of $\mathrm{N}-\mathrm{H}$ bond, as shown in Table 3. A first comparison among the IR spectra reported in Figure 4 showed that ammonia emission was different for these two kinds of coal. In fact, South Africa coal released vapors from 25 to $300^{\circ} \mathrm{C}$, showing IR absorption bands due to ammonia. On the other hand, the vapors emitted from Sulcis coal at low temperatures $\left(25-200^{\circ} \mathrm{C}\right)$ were mainly constituted by water and only traces of oxygenate compounds. Only starting from $300^{\circ} \mathrm{C}$, these vapors showed appreciable IR absorptions. The strong emission of $\mathrm{NH}_{3}$ by heating South Africa coal at low temperatures $\left(25-100^{\circ} \mathrm{C}\right)$ is due to the presence of both organic and mostly of inorganic nitrogen compounds, the latter being ammonium salts. On the contrary, Sulcis coal contains only organic nitrogen, lacking the inorganic one, and therefore the unique nitrogen compound emitted at relatively low temperatures (up to $300^{\circ} \mathrm{C}$ ) is $\mathrm{HCN}$. The different emissions of nitrogen compounds from these two kinds of coals are also confirmed by higher $\mathrm{NO}_{x}$ emissions observed from the combustion of South Africa coal, as underlined in a previous work [35]. Based on these considerations, the small difference of total nitrogen content in these two samples (about $0.3 \%$, as reported in Table 1 ) is ascribed to the inorganic nitrogen component contained in the South Africa coal.

The composition of the main pyrolysis products recovered from trap (b) was confirmed by GC-MS analysis. An example of a chromatogram obtained is reported in Figure 5(a).

In particular, Figure 5(b) reports a detail of the light ends present in the previous chromatogram.

Figure 5(b) enlargement clearly evidences the presence of $\mathrm{C}_{3}-\mathrm{C}_{5}$ saturated hydrocarbons and of $\mathrm{C}_{1}-\mathrm{C}_{3}$ alcohols. Furthermore, the presence of acetone and methyl ethyl ketone is confirmed.

The analysis on the condensates from the Sulcis coal showed a very similar GC profile once again evidencing an analogous composition of the hydrocarbon fractions coming from the two different coals and the formation of aliphatic hydrocarbons, alcohols, ketones, and aromatics.

The intensities of the analytical IR bands for the vapors which were collected in the liquid nitrogen trap (c) are 
TABLE 2: Qualitative distribution of vapors collected in the cooling trap (b) with solid $\mathrm{CO}_{2}+$ acetone.

\begin{tabular}{|c|c|c|c|c|c|c|c|c|c|}
\hline Coal & $T\left({ }^{\circ} \mathrm{C}\right)$ & $\mathrm{C}_{6} \mathrm{H}_{6}$ & $\mathrm{Me}-\mathrm{C}_{6} \mathrm{H}_{5}$ & n-Hydr. ${ }^{a}$ & $\mathrm{Me}_{2} \mathrm{CO}$ & $\mathrm{HCN}$ & Et-CO-Me & $\mathrm{NH}_{3}$ & Olefins \\
\hline \multirow{9}{*}{ Sulcis } & 25 & & & & & & & & \\
\hline & 100 & & & & & & & & \\
\hline & 200 & & & & & & & & \\
\hline & 300 & $\mathrm{w}$ & & $\mathrm{w}$ & & $\mathrm{w}$ & & & \\
\hline & 400 & $\mathrm{w}$ & $\mathrm{w}$ & $\mathrm{m}$ & $\mathrm{m}$ & $\mathrm{m}$ & $\mathrm{w}$ & & \\
\hline & 500 & $\mathrm{~m}$ & $\mathrm{~m}$ & $\mathrm{~s}$ & & $\mathrm{~m}$ & $\mathrm{w}$ & & $\mathrm{w}$ \\
\hline & 600 & $\mathrm{~s}$ & $\mathrm{~s}$ & s & $\mathrm{m}$ & s & $\mathrm{w}$ & & \\
\hline & 700 & $\mathrm{~m}$ & $\mathrm{~m}$ & $\mathrm{~m}$ & $\mathrm{w}$ & $\mathrm{m}$ & & $\mathrm{m}$ & \\
\hline & 800 & $\mathrm{~m}$ & $\mathrm{w}$ & $\mathrm{w}$ & & $\mathrm{w}$ & & $\mathrm{s}$ & \\
\hline \multirow{9}{*}{ South Africa } & 25 & & & & & & & $\mathrm{~m}$ & \\
\hline & 100 & & & & & & & $\mathrm{~m}$ & \\
\hline & 200 & & & $\mathrm{w}$ & & & & $\mathrm{w}$ & \\
\hline & 300 & & & $\mathrm{w}$ & & & & $\mathrm{w}$ & \\
\hline & 400 & & & $\mathrm{~m}$ & & & & & \\
\hline & 500 & $\mathrm{~m}$ & $\mathrm{~s}$ & s & $\mathrm{w}$ & & $\mathrm{w}$ & & $\mathrm{m}$ \\
\hline & 600 & $\mathrm{~s}$ & s & $\mathrm{s}$ & $\mathrm{w}$ & & $\mathrm{w}$ & & $\mathrm{m}$ \\
\hline & 700 & $\mathrm{~s}$ & $\mathrm{~m}$ & $\mathrm{~m}$ & & $\mathrm{~m}$ & & $\mathrm{~m}$ & \\
\hline & 800 & $\mathrm{w}$ & & $\mathrm{w}$ & & $\mathrm{w}$ & & $\mathrm{m}$ & \\
\hline
\end{tabular}

Intensity of analytical bands: w: weak; m: medium, s: strong; Me: methyl group; Et: ethyl group.

${ }^{\mathrm{a}}$ : n-hydrocarbons.

TABLE 3: Infrared absorptions range and analytical IR bands for considered vapors and gases.

\begin{tabular}{|c|c|c|c|c|c|c|}
\hline Sample & Formula & Range $\left(\mathrm{cm}^{-1}\right)$ & Assignment & Range $\left(\mathrm{cm}^{-1}\right)$ & Assignment & $\begin{array}{c}\text { Analytical bands } \\
\left(\mathrm{cm}^{-1}\right)\end{array}$ \\
\hline Methane & $\mathrm{CH}_{4}$ & $3200-2900$ & $v_{\mathrm{C}-\mathrm{H}}$ & $1350-1250$ & $\delta_{\mathrm{C}-\mathrm{H}}$ & 3015,1307 \\
\hline Hydrocarbons & $\mathrm{HC}$ & $3200-2800$ & $v_{\mathrm{C}-\mathrm{H}}$ & $1450-1370$ & $\delta_{\mathrm{C}-\mathrm{H}}$ & 2950 \\
\hline Hydrocarbons uns. & $\mathrm{C}=\mathrm{C}$ & $3200-3000$ & $v_{=\mathrm{C}-\mathrm{H}}$ & $1100-800$ & $\gamma_{\mathrm{C}-\mathrm{H}}$ & $1663,913,890^{*}$ \\
\hline Ethylene & $\mathrm{C}_{2} \mathrm{H}_{4}$ & $3200-3000$ & $v_{=\mathrm{C}-\mathrm{H}}$ & $1100-900$ & $\gamma_{\mathrm{C}-\mathrm{H}}$ & 1890,950 \\
\hline Acetylene & $\mathrm{C}_{2} \mathrm{H}_{2}$ & $3300-3250$ & $v_{\mathrm{C}-\mathrm{H}}$ & $700-610$ & $\gamma_{\mathrm{C}-\mathrm{H}}$ & 730 \\
\hline Carbon dioxide & $\mathrm{CO}_{2}$ & $2500-2200$ & $v_{\mathrm{asC}=\mathrm{O}}$ & $700-600$ & $\delta_{\mathrm{C}=\mathrm{O}}$ & 2350 \\
\hline Carbon monoxide & $\mathrm{CO}$ & $2250-2050$ & $v_{\mathrm{CO}}$ & - & - & 2120 \\
\hline Carbon disulpfhide & $\mathrm{CS}_{2}$ & $1550-1450$ & $v_{\mathrm{C}=\mathrm{S}}$ & - & - & 1537 \\
\hline sulphur Dioxide & $\mathrm{SO}_{2}$ & $1400-1300$ & $v_{\mathrm{S}=\mathrm{O}}$ & $1250-1100$ & $\delta_{\mathrm{S}=\mathrm{O}}$ & 1133 \\
\hline Carbonyl Sulphide & COS & $2100-1970$ & $v_{\mathrm{C}=\mathrm{O}}$ & $900-800$ & $\delta_{\mathrm{S}=\mathrm{C}=\mathrm{O}}$ & 2070 \\
\hline Benzene & $\mathrm{C}_{6} \mathrm{H}_{6}$ & $1500-1400$ & $v_{\mathrm{C}=\mathrm{C}}$ & $1100-1000$ & r-ring & 3030,674 \\
\hline Toluene & $\mathrm{C}_{6} \mathrm{H}_{5}-\mathrm{CH}_{3}$ & $1665-1430$ & $v_{\mathrm{C}=\mathrm{C}}$ & $800-650$ & r-ring & 729,694 \\
\hline $\mathrm{MAH}$ & $\mathrm{C}_{6} \mathrm{H}_{5}-\mathrm{X}$ & $1665-1430$ & $v_{\mathrm{C}=\mathrm{C}}$ & $910-665$ & r-ring & $\begin{array}{c}741,769,796,910 \\
776^{* *}\end{array}$ \\
\hline Methanol & $\mathrm{CH}_{3}-\mathrm{OH}$ & $3700-2400$ & $v_{\mathrm{OH}}$ & $1050-950$ & $v_{\mathrm{C}-\mathrm{OH}}$ & 1054 \\
\hline Acetone & $\mathrm{CH}_{3}-\mathrm{CO}-\mathrm{CH}_{3}$ & $2000-1500$ & $v_{\mathrm{C}=\mathrm{O}}$ & $1200-1050$ & $\delta_{\mathrm{C}=\mathrm{O}}$ & 1220 \\
\hline Ammonia & $\mathrm{NH}_{3}$ & $1800-1400$ & $s_{\mathrm{H}-\mathrm{N}-\mathrm{H}}$ & $1250-680$ & $\mathrm{w}_{\mathrm{N}-\mathrm{H}}$ & 968 \\
\hline Hydrocyanic acid & $\mathrm{HCN}$ & $3400-3200$ & $v_{\mathrm{CH},} v_{\mathrm{CN}}$ & $750-650$ & $\delta_{\mathrm{C}-\mathrm{H}}$ & 3312,712 \\
\hline Nitrous oxide & $\mathrm{N}_{2} \mathrm{O}$ & $2300-2000$ & $v_{\mathrm{NN}}$ & - & - & 2240 \\
\hline Nitrogen oxide & NO & $2000-1800$ & $v_{\mathrm{N}=\mathrm{O}}$ & - & - & 1875 \\
\hline Nitrogen dioxide & $\mathrm{NO}_{2}$ & $1700-1550$ & $v_{\mathrm{N}-\mathrm{O}}$ & - & - & 1625 \\
\hline
\end{tabular}

MAH: mononuclear aromatic hydrocarbons; X: ethyl, isopropyl groups $v$ : stretching vibration; deformations: $\delta$ : in plane $\gamma$ : out-of-plane r: rocking, s: scissoring, and w: wagging.

${ }^{*}$ For propylene, isobutene; ${ }^{* *}$ For o-Xylene, m-Xylene, p-Xylene, isopropyl-benzene, and ethyl-benzene. 


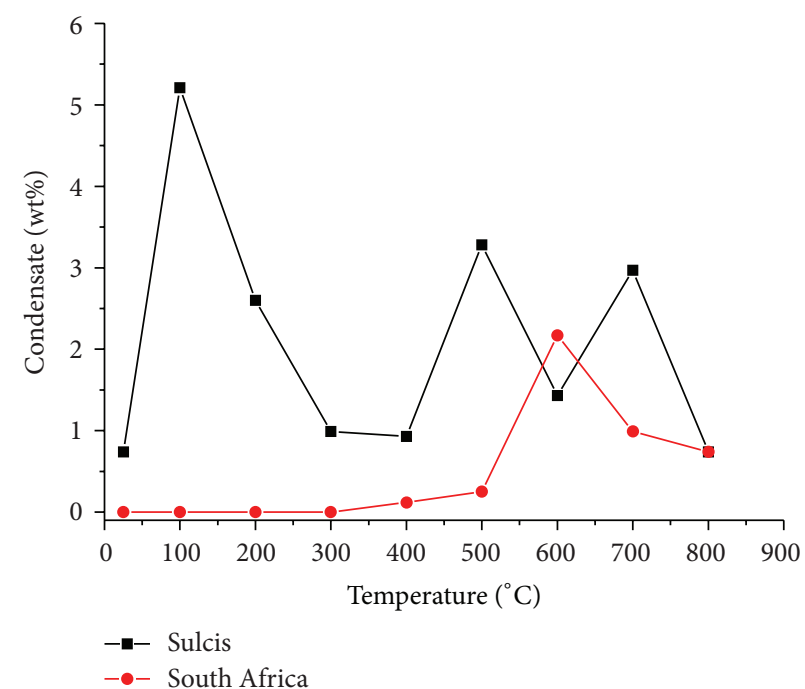

(a)

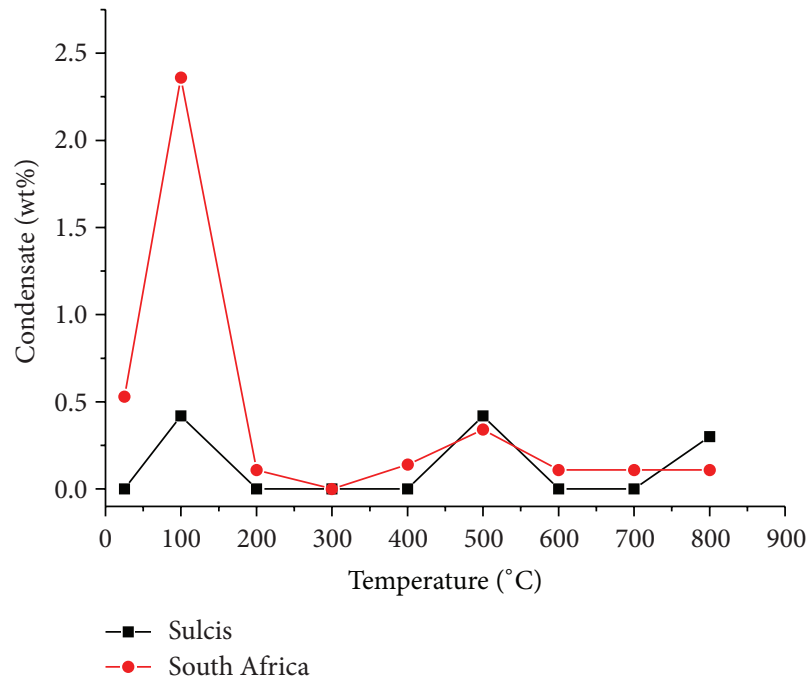

(b)

Figure 2: (a) Amount (wt\%) of liquid materials collected in the cooling trap (a) against heating temperature. (b) Amount (wt\%) of liquid materials collected in the cooling trap (b) against temperature.

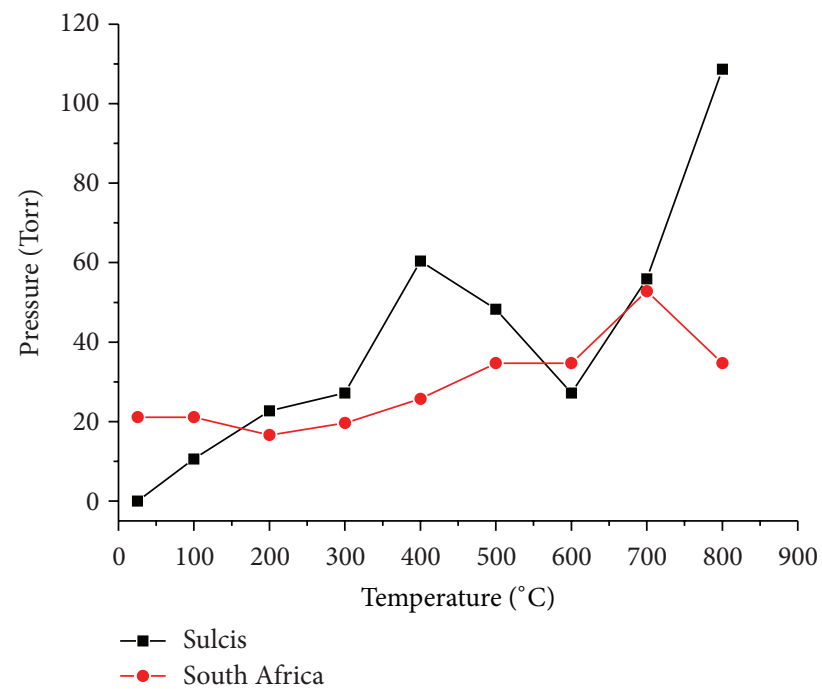

(a)

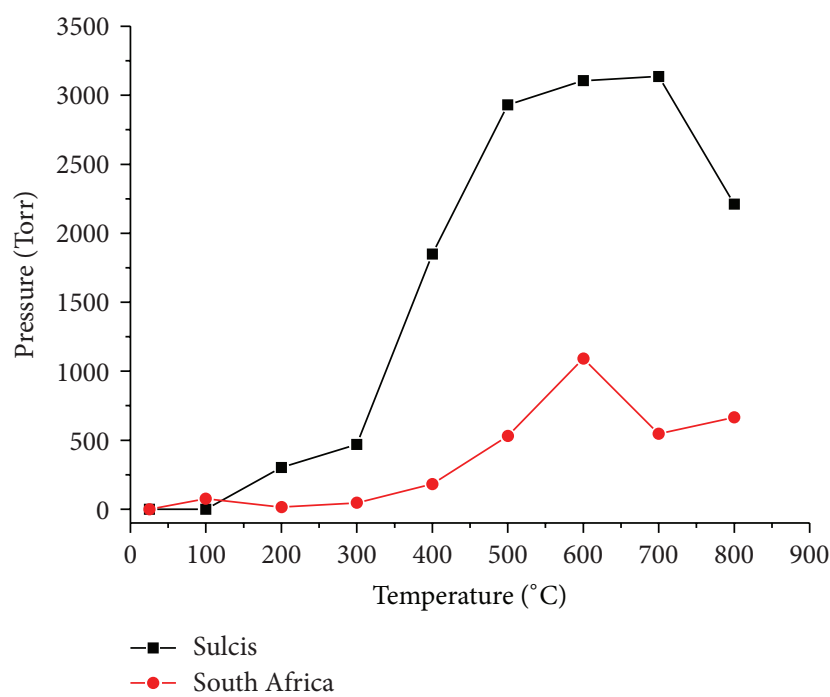

(b)

Figure 3: (a) Pressure values against temperature of vapors released by coals and collected in the trap (b) cooled at $-77^{\circ} \mathrm{C}$. (b) Pressure values against temperature of gases released by coals and collected in the trap (c) cooled at $-180^{\circ} \mathrm{C}$.

reported in Table 4, while Figure 6 shows the corresponding IR spectra at different temperatures of emission.

With the FT-IR analysis of this fraction, products such as $\mathrm{CO}_{2}, \mathrm{COS}, \mathrm{SO}_{2}, \mathrm{Me}_{2} \mathrm{CO}, \mathrm{CS}_{2}, \mathrm{HCN}, \mathrm{Me}_{2} \mathrm{C}=\mathrm{CH}_{2}, \mathrm{C}_{2} \mathrm{H}_{4}$, $\mathrm{MeCH}=\mathrm{CH}_{2}, \mathrm{C}_{2} \mathrm{H}_{6}, \mathrm{Et}_{2} \mathrm{O}$, and $\mathrm{C}_{3} \mathrm{H}_{8}+\mathrm{C}_{4} \mathrm{H}_{10}$ were identified.

The overall comparison between Figure 6 and Table 4 shows that $\mathrm{CO}_{2}$ was emitted continuously by both coals at all temperatures above $200^{\circ} \mathrm{C}$. One of its bands of interest was in the range $700-600 \mathrm{~cm}^{-1}$ and it was due to the bending of $\mathrm{C}=\mathrm{O}$ bond (Table 3 ). Hydrocarbons were emitted at temperatures above $400^{\circ} \mathrm{C}$ for both coals (Figure 6 and Table 4). Identification of unsaturated hydrocarbons was performed by evaluating the bands in the range $1100-800 \mathrm{~cm}^{-1}$, due to the bending out of plane of $\mathrm{C}-\mathrm{H}$ bond (Table 3). Saturated ones showed the absorption bands in the range $3200-2800 \mathrm{~cm}^{-1}$, due to the stretching of $\mathrm{C}-\mathrm{H}$ bond (Table 3 ).

$\mathrm{SO}_{2}$ was emitted between 200 and $300^{\circ} \mathrm{C}$ for Sulcis coal (Figure 6 and Table 4), and it was identified on the basis of the band in the range $1400-1300 \mathrm{~cm}^{-1}$, due to the stretching of $\mathrm{S}=\mathrm{O}$ bond (Table 3 ). On the other hand, COS was emitted from Sulcis coal, and it was recognized from the stretching of $\mathrm{C}=\mathrm{O}$ bond in the range $2100-1970 \mathrm{~cm}^{-1}$ (Table 3). Finally, $\mathrm{CS}_{2}$ was emitted significantly from both coals between 500 and $600^{\circ} \mathrm{C}$ (Figure 6 and Table 4), and it was identified from the 
TABLE 4: Qualitative distribution of vapors collected in the cooling trap (c) with liquid nitrogen.

\begin{tabular}{|c|c|c|c|c|c|c|c|c|c|c|c|c|c|}
\hline Coal & $T\left({ }^{\circ} \mathrm{C}\right)$ & $\mathrm{CO}_{2}$ & $\mathrm{COS}$ & $\mathrm{SO}_{2}$ & $\mathrm{Me}_{2} \mathrm{CO}$ & $\mathrm{CS}_{2}$ & $\mathrm{HCN}$ & $\mathrm{Me}_{2} \mathrm{C}=\mathrm{CH}_{2}$ & $\mathrm{C}_{2} \mathrm{H}_{4}$ & $\mathrm{MeCH}=\mathrm{CH}_{2}$ & $\mathrm{C}_{2} \mathrm{H}_{6}$ & $\mathrm{Et}_{2} \mathrm{O}$ & $\mathrm{C}_{3} \mathrm{H}_{8}+\mathrm{C}_{4} \mathrm{H}_{10}$ \\
\hline \multirow{7}{*}{ Sulcis } & 200 & $s$ & $\mathrm{~m}$ & s & $\mathrm{m}$ & & & & & & & & \\
\hline & 300 & s & $\mathrm{s}$ & s & $\mathrm{m}$ & $\mathrm{w}$ & $\mathrm{w}$ & $\mathrm{w}$ & & & & & \\
\hline & 400 & $\mathrm{~s}$ & s & $\mathrm{m}$ & $\mathrm{m}$ & $\mathrm{m}$ & $\mathrm{m}$ & s & $\mathrm{w}$ & $\mathrm{w}$ & s & & $\mathrm{m}$ \\
\hline & 500 & s & $\mathrm{s}$ & & $\mathrm{w}$ & $\mathrm{w}$ & $\mathrm{m}$ & $\mathrm{w}$ & $\mathrm{s}$ & $\mathrm{m}$ & $\mathrm{s}$ & & $\mathrm{m}$ \\
\hline & 600 & $\mathrm{~s}$ & s & & $\mathrm{w}$ & $\mathrm{w}$ & $\mathrm{m}$ & $\mathrm{w}$ & s & $\mathrm{m}$ & $\mathrm{m}$ & & $\mathrm{m}$ \\
\hline & 700 & s & s & & & & $\mathrm{m}$ & & $\mathrm{m}$ & $\mathrm{w}$ & & & \\
\hline & 800 & $\mathrm{~s}$ & $\mathrm{~s}$ & & & & $\mathrm{w}$ & & $\mathrm{m}$ & & & & \\
\hline \multirow{8}{*}{ South Africa } & 100 & $\mathrm{~m}$ & & & & & & & & & & $\mathrm{w}$ & \\
\hline & 200 & & & & & & & & & & & $\mathrm{w}$ & \\
\hline & 300 & $\mathrm{w}$ & & & & & & & & & & & \\
\hline & 400 & $\mathrm{~s}$ & $\mathrm{w}$ & $\mathrm{w}$ & $\mathrm{w}$ & & & $\mathrm{w}$ & $\mathrm{w}$ & $\mathrm{w}$ & & & $\mathrm{m}$ \\
\hline & 500 & $\mathrm{~s}$ & $\mathrm{~m}$ & & $\mathrm{~m}$ & $\mathrm{~s}$ & $\mathrm{~m}$ & $\mathrm{~s}$ & $\mathrm{~s}$ & $\mathrm{~s}$ & $\mathrm{~s}$ & & $\mathrm{~s}$ \\
\hline & 600 & s & $\mathrm{m}$ & & & $\mathrm{m}$ & $\mathrm{w}$ & $\mathrm{w}$ & s & $\mathrm{s}$ & $s$ & & s \\
\hline & 700 & s & $\mathrm{m}$ & & & $\mathrm{w}$ & $\mathrm{m}$ & & s & $\mathrm{w}$ & s & & $\mathrm{m}$ \\
\hline & 800 & $\mathrm{~s}$ & $\mathrm{w}$ & & & & $\mathrm{m}$ & & $\mathrm{m}$ & & & & $\mathrm{w}$ \\
\hline
\end{tabular}

Intensity of analytical bands: w: weak; m: medium, s: strong: Me: methyl group; Et: ethyl group.

stretching of $\mathrm{C}=\mathrm{S}$ bond in the range $1550-1450 \mathrm{~cm}^{-1}$, showing a characteristic doublet.

In our system, thermal cracking of tar molecules causes ring opening reactions, thereby releasing nitrogen into the gas phase as $\mathrm{NO}_{x}$ precursors, primarily as $\mathrm{HCN}$, but also as $\mathrm{NH}_{3}$ and $\mathrm{HNCO}[39,40]$. The release of $\mathrm{HCN}$ can be explained on the basis of the reaction:

$$
\mathrm{CO}+\mathrm{NH}_{3} \longrightarrow \mathrm{HCN}+\mathrm{H}_{2} \mathrm{O}
$$

Furthermore, it has also been suggested that HCN can react with $\mathrm{H}_{2}$ to form $\mathrm{NH}_{3}$ [41].

Sulfur is present in coal in organic phase (classified as aliphatic, aromatic, and thiophenic sulfur) and inorganic phase, being pyrite $\left(\mathrm{FeS}_{2}\right)$ and sulphates [42]. Coal pyrolysis releases sulfur as gas species $\left(\mathrm{H}_{2} \mathrm{~S}, \mathrm{COS}, \mathrm{SO}_{2}\right.$, and $\left.\mathrm{CS}_{2}\right)$ and mercaptans in the tar phase, while the rest remains in the solid matrix of the residual char [43]. Generally, $\mathrm{H}_{2} \mathrm{~S}$ is the most abundant gaseous component, and there is usually a significant amount of mercaptans too [41]. In other cases, large amounts of $\mathrm{SO}_{2}$ are also revealed [44]. The following reactions can explain the formation of these compounds:

$$
\begin{gathered}
\mathrm{CH}_{4}+\frac{4}{x} \mathrm{~S}_{x} \longrightarrow \mathrm{CS}_{2}+2 \mathrm{H}_{2} \mathrm{~S} \quad\left(T=500-700^{\circ} \mathrm{C}\right) \\
\mathrm{CH}_{4}+\frac{2}{x} \mathrm{~S}_{x} \longrightarrow \mathrm{CS}_{2}+2 \mathrm{H}_{2} \quad\left(T>700^{\circ} \mathrm{C}\right) \\
\mathrm{S}+\mathrm{O}_{2} \longrightarrow \mathrm{SO}_{2} \\
3 \mathrm{~S}+2 \mathrm{H}_{2} \mathrm{O} \longrightarrow \mathrm{SO}_{2}+2 \mathrm{H}_{2} \mathrm{~S} \\
3 \mathrm{~S}+2 \mathrm{CO}_{2} \longrightarrow 2 \mathrm{COS}+\mathrm{SO}_{2}
\end{gathered}
$$

where $S_{x}$ indicates that the sulphur in the vapour state has a various molecular complexity $\mathrm{S}_{2}, \mathrm{~S}_{6}$, and $\mathrm{S}_{8}$.
In addition, COS will be formed by secondary gas phase reactions $[45,46]$ :

$$
\begin{gathered}
\mathrm{H}_{2} \mathrm{~S}+\mathrm{CO} \longrightarrow \mathrm{COS}+\mathrm{H}_{2}, \\
\mathrm{H}_{2} \mathrm{~S}+\mathrm{CO}_{2} \longrightarrow \mathrm{COS}+\mathrm{H}_{2} \mathrm{O} .
\end{gathered}
$$

In nitrogen atmosphere, pyrite is transformed into iron sulfide at low sulphur content, pyrrhotite $\operatorname{FeS}_{n}(1 \leq n \leq 2)$ [47], and into the very reactive $S^{\circ}$. Both species may react with $\mathrm{H}_{2}$ produced from coal and forming $\mathrm{H}_{2} \mathrm{~S}$ or with the carbonaceous matrix to form organic/inorganic sulfur, which remains trapped in tar or char [48].

In addition, the following reactions may occur [49]:

$$
\begin{gathered}
\mathrm{FeS}_{2} \longrightarrow \mathrm{FeS}+\mathrm{S}, \\
\mathrm{FeS}_{2}+\mathrm{H}_{2} \longrightarrow \mathrm{FeS}+\mathrm{H}_{2} \mathrm{~S}, \\
2 \mathrm{SO}_{2}+4 \mathrm{C} \longrightarrow 4 \mathrm{CO}+\mathrm{S}_{2} .
\end{gathered}
$$

In this reaction environment, a gas-solid reaction may occur between pyrite and the formed CO [46]:

$$
\mathrm{FeS}_{2}+\mathrm{CO} \longrightarrow \mathrm{FeS}+\mathrm{COS} .
$$

Finally, the emission of $\mathrm{CO}_{x}$ can take place from the following reactions:

$$
\begin{gathered}
\mathrm{C}+\frac{1}{2} \mathrm{O}_{2} \longrightarrow \mathrm{CO} \\
\mathrm{CO}+\frac{1}{2} \mathrm{O}_{2} \longrightarrow \mathrm{CO}_{2}, \\
\mathrm{C}+\mathrm{O}_{2} \longrightarrow \mathrm{CO}_{2}, \\
\mathrm{C}+\mathrm{H}_{2} \mathrm{O} \longrightarrow \mathrm{CO}+\mathrm{H}_{2}, \\
\mathrm{C}+2 \mathrm{H}_{2} \mathrm{O} \longrightarrow \mathrm{CO}+\mathrm{H}_{2} .
\end{gathered}
$$




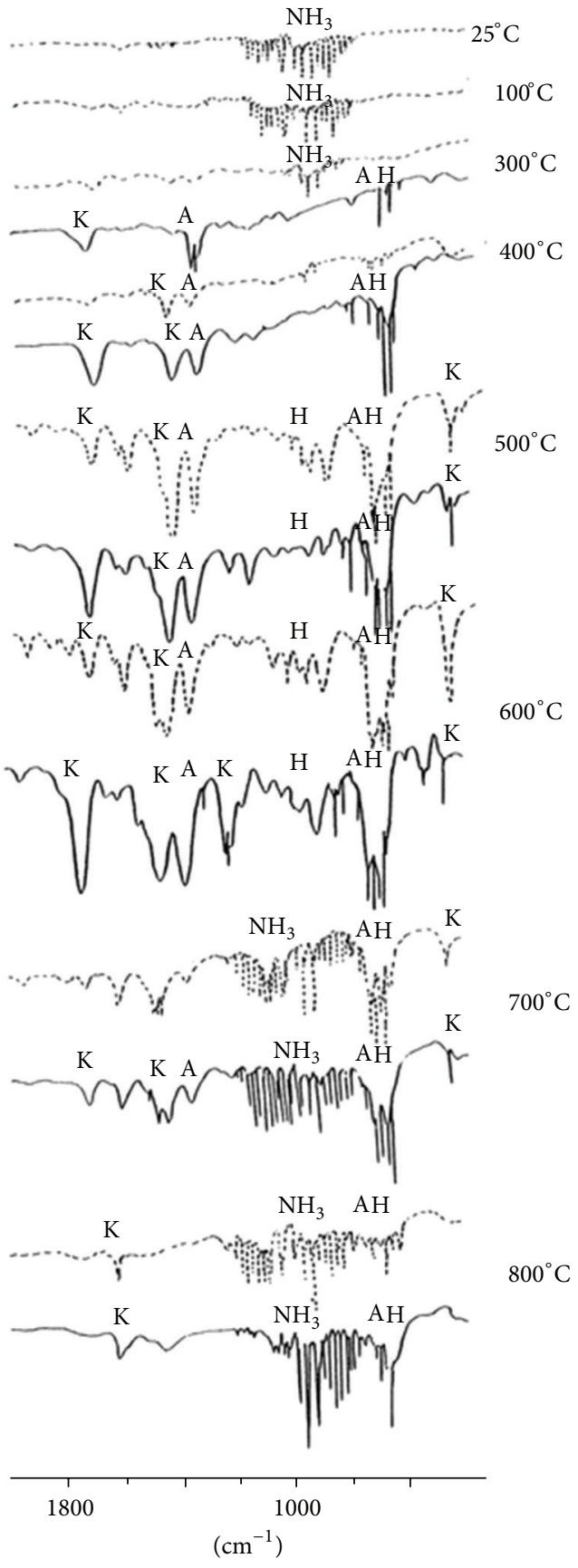

FIgURE 4: FT-IR spectra in $2000-400 \mathrm{~cm}^{-1}$ region of vapors obtained at different temperatures from Sulcis (-) and South Africa (- -) coals sampled in the cooling trap (b). $\mathrm{K}=$ ketones, $\mathrm{A}=$ aromatic hydrocarbons, and $\mathrm{H}=$ aliphatic hydrocarbons (saturated and unsaturated).

In the earlier reactions, the adsorbed oxygen in the carbonaceous matrix (deriving from air of the environment) is released during the pyrolysis process.

Furthermore, these components can be originated at high temperatures by following the reactions [50]

$$
\mathrm{CaCO}_{3} \longrightarrow \mathrm{CaO}+\mathrm{CO}_{2} \quad\left(T>700^{\circ} \mathrm{C}\right)
$$

$$
\begin{gathered}
\mathrm{CaSO}_{4}+2 \mathrm{C} \longrightarrow \mathrm{CaS}+2 \mathrm{CO}_{2} \quad\left(T=700-800^{\circ} \mathrm{C}\right) \\
\mathrm{CaSO}_{4}+4 \mathrm{C} \longrightarrow \mathrm{CaS}+4 \mathrm{CO} \quad\left(T=800^{\circ} \mathrm{C}\right) .
\end{gathered}
$$

The overall comparison of the IR spectra evidences that both coals present a similar qualitative composition of the products obtained at high values of temperature. Moreover, it is important to observe that the pyrolysis products for the two coals are quantitatively different. Sulcis coal releases higher amounts of pyrolysis products at a lower temperature than the South Africa one, since the former is a lower rank coal. In fact, Sulcis coal is richer in volatile matter $\left(V_{m}\right)$ than South African coal, as evidenced in Table 1 . This aspect justifies the lower temperature of decomposition of the Sulcis coal (between 100 and $200^{\circ} \mathrm{C}$ ) than that of the South African one (between 300 and $400^{\circ} \mathrm{C}$ ) (Figures 2(a) and 2(b)). In fact, the temperature at which the decomposition starts is directly related to the average energy required to break the bonds in the coal macrostructures.

In agreement with the literature data [51], sulphur derivatives such as $\mathrm{SO}_{2}$, COS, and $\mathrm{CS}_{2}$ can be identified as pyrolysis products. In particular, Sulcis coal emitted $\mathrm{SO}_{2}, \mathrm{COS}$, and $\mathrm{CS}_{2}$, while South Africa coal released smaller quantities of $\mathrm{SO}_{2}$ and COS. This is fully in agreement with their different total sulphur content (5.9 versus $0.6 \%$ for Sulcis and South Africa coal, resp.).

The evolved amount of these products is a function of the temperature. In fact, while the quantity of COS constantly increases with temperature until $600^{\circ} \mathrm{C}$ for both fossils, $\mathrm{SO}_{2}$ is mainly collected for Sulcis coal only between 200 and $300^{\circ} \mathrm{C}$ and in a small amount in the other case. COS derives from the organic sulphur (e.g., thioethers), while $\mathrm{SO}_{2}$ from the inorganic matrix, consisting mainly in elemental sulphur, sulphide, sulphate, and pyrite.

In the case of South Africa coal, it is important to note that it has a singular behaviour at low temperatures. Small quantities of $\mathrm{CO}_{2}$ and oxygenated compounds, such as acetone and diethyl ketone, were revealed during the heating at $100^{\circ} \mathrm{C}$. These quantities decreased at $200^{\circ} \mathrm{C}$ and disappeared at $500^{\circ} \mathrm{C}$. From $400^{\circ} \mathrm{C}$ its decomposition was similar to the other coal. This behaviour is in agreement with a molecular sieve structure type that contains some molecules such as $\mathrm{CO}_{2}, \mathrm{CO}$ and other oxygenated compounds, trapped inside the pores of the solid matrix [52]. Their formation is due to absorbed oxygen by air of the environment. In fact, as soon as fresh coal is mined and exposed to atmospheric conditions, the process of slow oxidation due to contact with air inexorably sets in [18].

In Figure 7(a), pressure values of noncondensable gases are reported as a function of temperature for both coals.

Figure 7(a) shows that noncondensable gases coming from both types of coal are emitted significantly starting from $400^{\circ} \mathrm{C}$ and their trends are almost similar.

In Figure 7(b), the FT-IR spectra of these noncondensable gases are shown at different temperatures of emission for Sulcis and South Africa coals.

The IR spectra of the noncondensable gases reveal bands ascribed to methane and carbon monoxide and small 


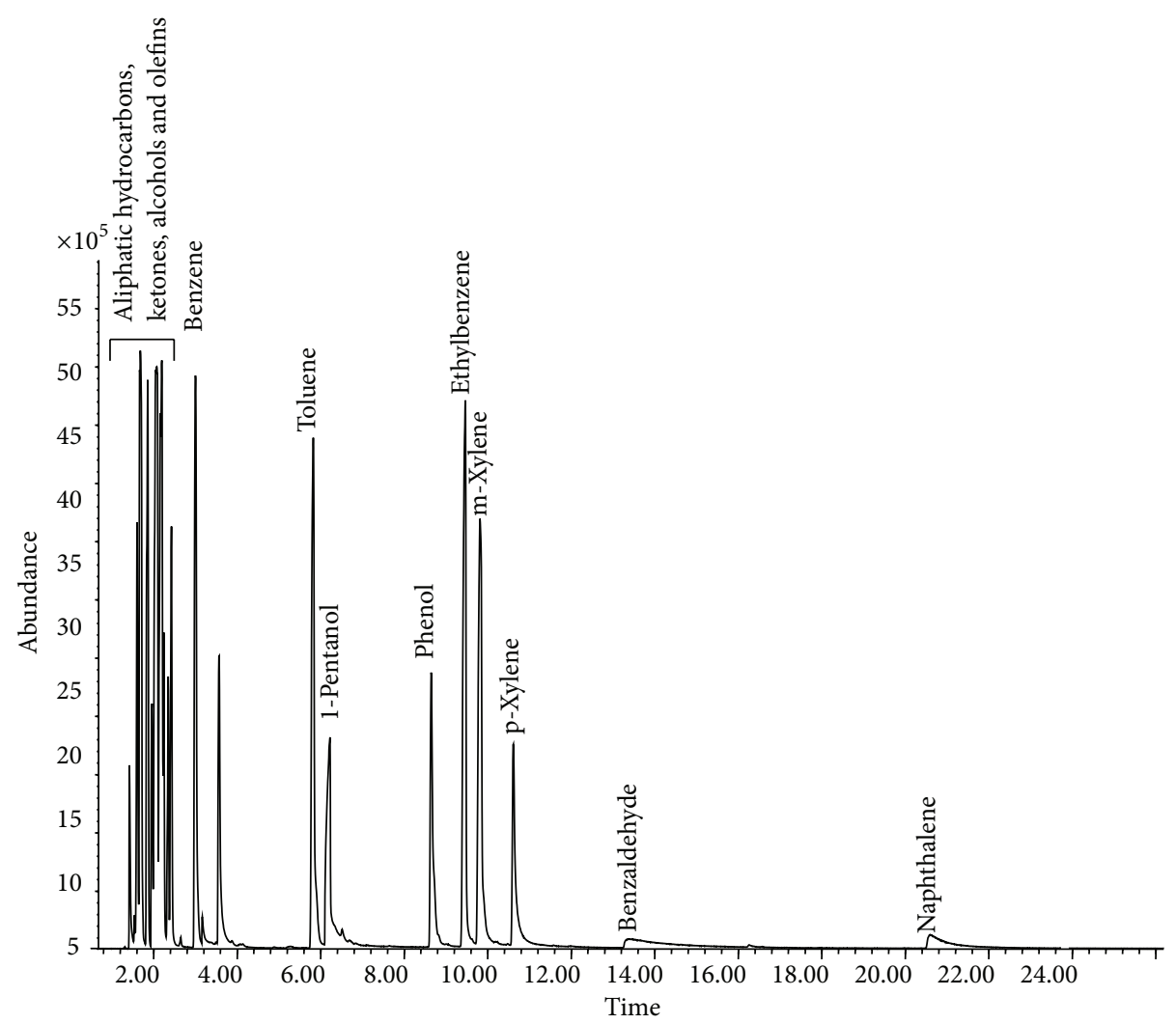

(a)

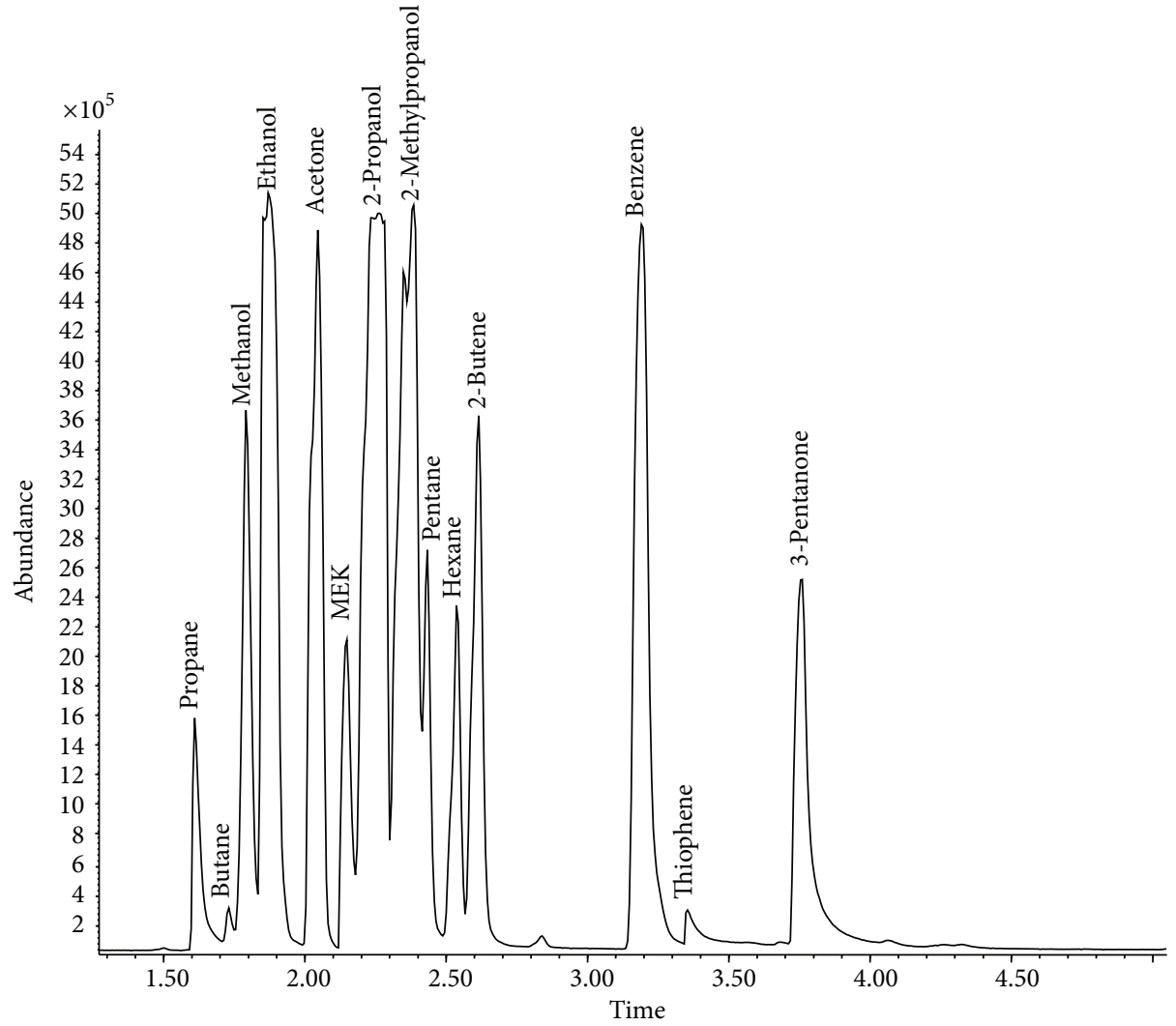

(b)

Figure 5: (a) GC-MS chromatogram of the condensate (trap b) coming from the devolatilization of the South Africa coal at $600^{\circ}$ C. (b) Particularity of the light ends in the GC-MS chromatogram of the condensate (trap b) coming from the devolatilization of the South Africa coal at $600^{\circ} \mathrm{C}$. 

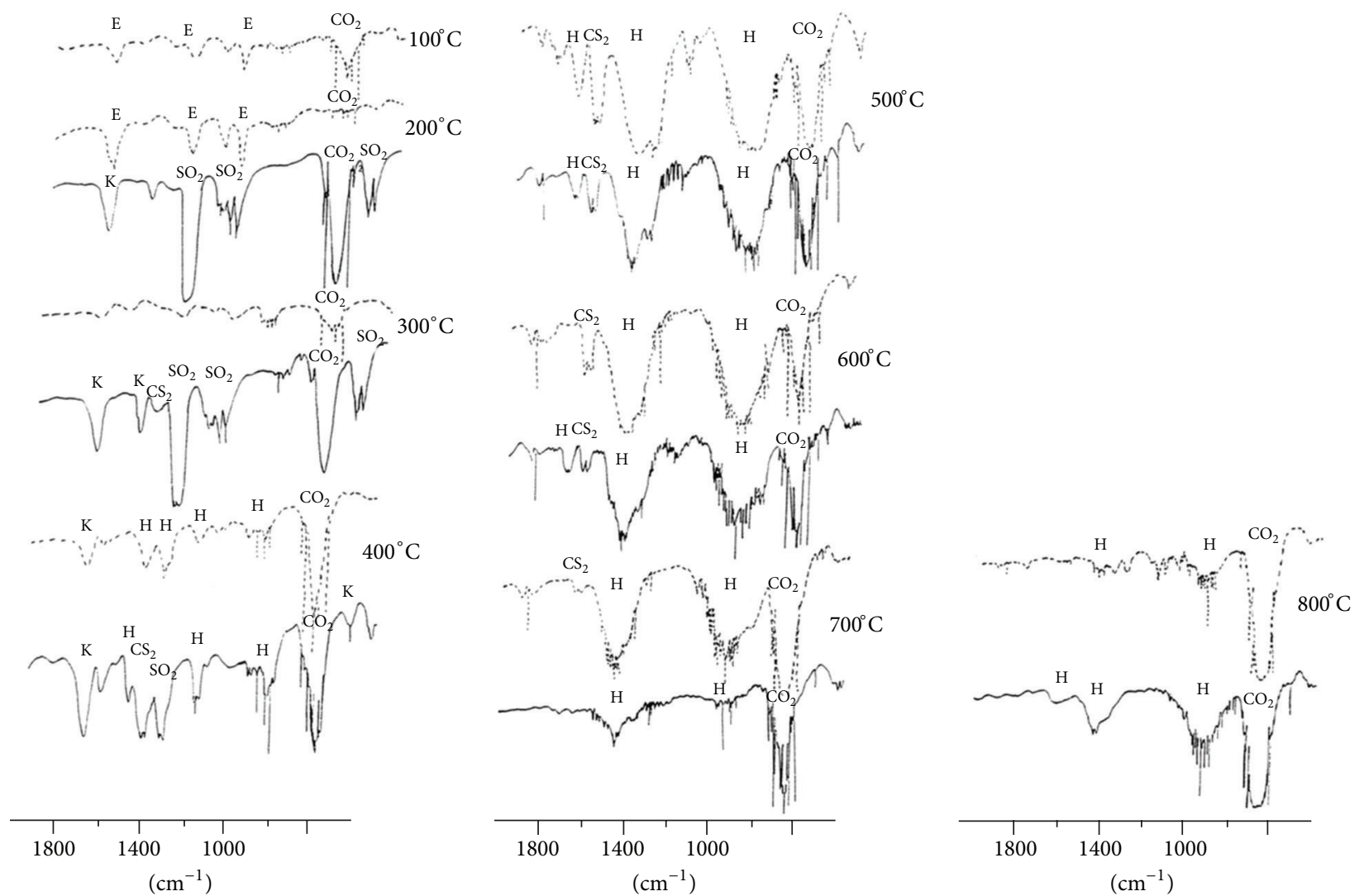

FIGURE 6: FT-IR spectra in the $2000-400 \mathrm{~cm}^{-1}$ region of gases obtained at different temperatures from Sulcis (-) and South Africa (- - -) coals sampled in the cooling trap (c). $\mathrm{E}=$ ethers, $\mathrm{K}=$ ketones, $\mathrm{H}=$ aliphatic hydrocarbons (saturated and unsaturated).

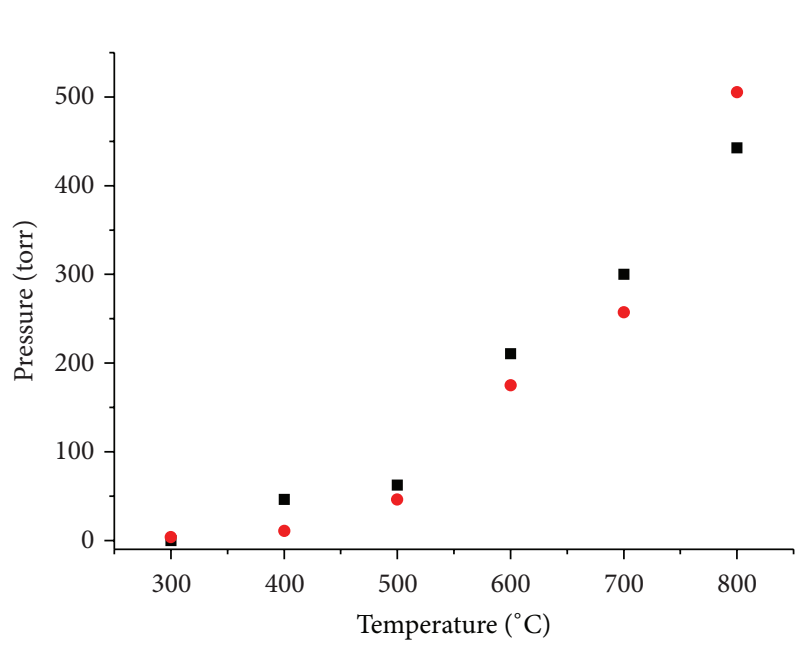

- Sulcis

- South Africa

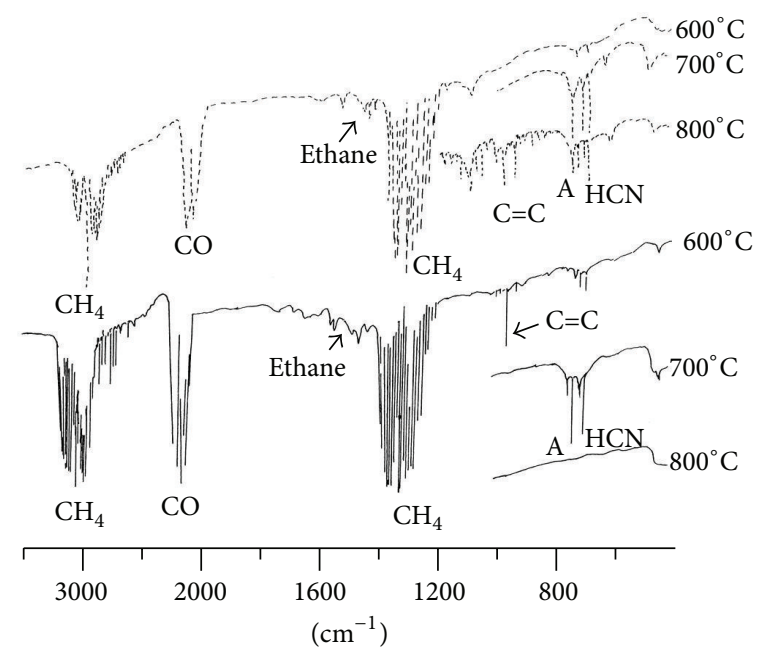

(b)

FIgure 7: (a) Plots of the pressure values of noncondensable gases against temperatures for Sulcis and South Africa coals. (b) FT-IR spectra in $3500-400 \mathrm{~cm}^{-1}$ region of noncondensable gases obtained at various temperatures by Sulcis $(-)$ and South Africa coals $(---)$. A = acetylene. 


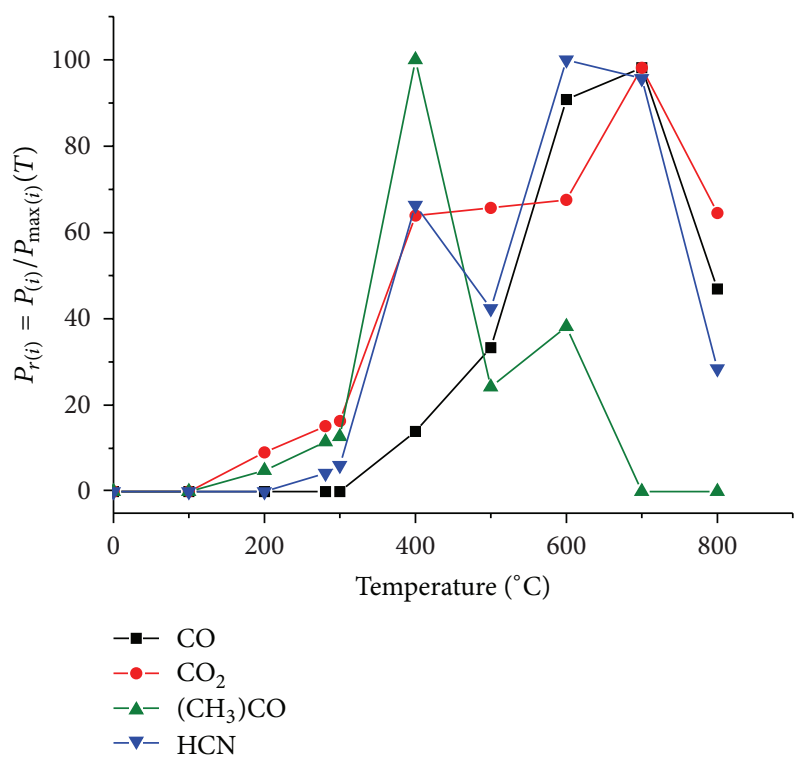

(a)

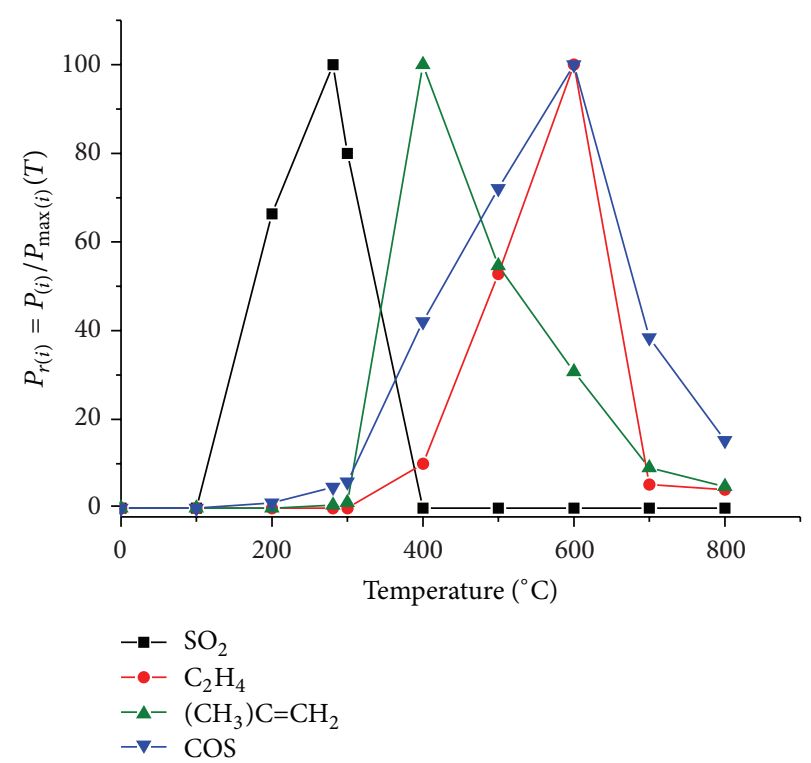

(b)

Figure 8: (a) Relative pressure values of $\left(\mathrm{CH}_{3}\right)_{2} \mathrm{CO}, \mathrm{HCN}, \mathrm{CO}$, and $\mathrm{CO}_{2}$ against temperature for Sulcis coal. (b) Relative pressure values of $\left(\mathrm{CH}_{3}\right)_{2} \mathrm{C}=\mathrm{CH}_{2}, \mathrm{SO}_{2}, \mathrm{C}_{2} \mathrm{H}_{4}$, and $\mathrm{COS}$ against temperature for Sulcis coal.

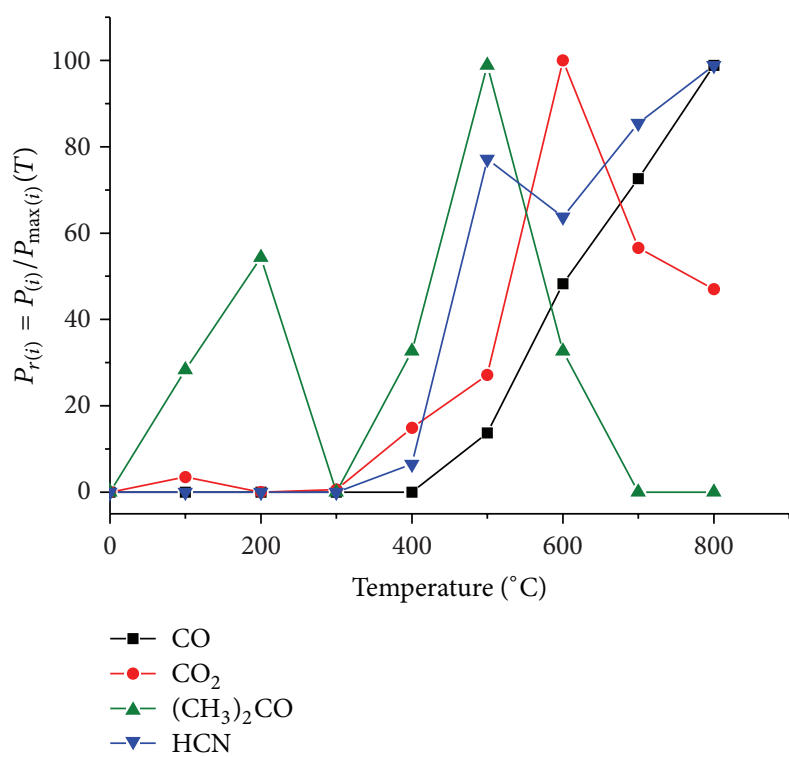

(a)

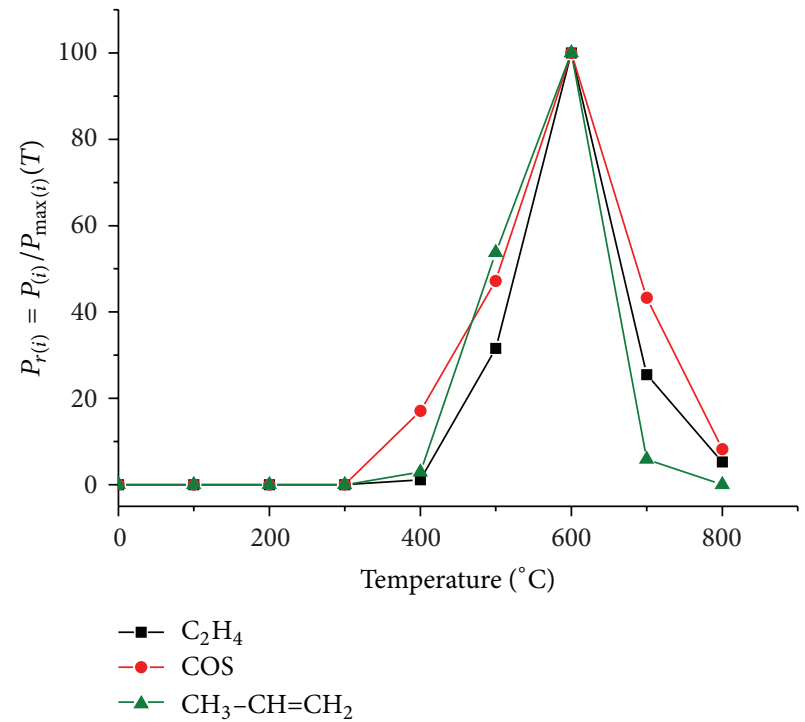

(b)

Figure 9: (a) Relative pressure values of $\mathrm{CO}, \mathrm{CO}_{2},\left(\mathrm{CH}_{3}\right)_{2} \mathrm{CO}$, and $\mathrm{HCN}$ against temperature for South Africa coal. (b) Relative pressure values of $\mathrm{C}_{2} \mathrm{H}_{4}, \mathrm{CH}_{3}-\mathrm{CH}=\mathrm{CH}_{2}$, and $\mathrm{COS}$ against temperature for South Africa coal.

amounts of ethane, unsaturated hydrocarbons, and acetylene. Furthermore, in the same spectra, the absorption bands due to $\mathrm{HCN}$ were found, probably because a part of the total $\mathrm{HCN}$, evolved during the pyrolysis process, has not been completely condensed in the previous traps. However, when the temperature increases, the $\mathrm{HCN}$ emission increases up to a maximum and then decreases. This pattern is similar also for the other pyrolysis products, recovered from the cooling traps (b) and (c). In fact, the global comparison between the
IR data of the condensates collected in the cooling trap (b) (with $\mathrm{CO}_{2}+$ acetone) (Figure 4, Table 2) and those of the condensates collected in the cooling trap (c) (with liquid nitrogen) (Figure 6, Table 4) shows that absorption bands intensities of each pyrolysis product increase with the temperature until a maximum zone and then they decrease. In order to better define the maximum emission for some of the pyrolysis products, after having identified most of the vapors and gases (Table 3 ) on the basis of assignments reported in 
the literature [53], the analytical bands of interest were chosen and standard mixtures of the gas samples corresponding to the pyrolysis products were prepared. These calibration mixtures containing known amounts of gas were introduced into an evacuated gas cell, which was subsequently filled to a pressure of one atmosphere with nitrogen. In Figures 8(a), 8(b), 9(a), and 9(b), the relative pressure $P_{r(i)}=P_{(i)}\left(T_{r}\right) /$ $P_{\max (i)}\left(T_{e}\right)$ is plotted against temperature for Sulcis and South Africa coal, respectively: $P_{(i)}$ is the partial pressure of $i$ component in the mix at room temperature $\left(T_{r}\right)$, and $P_{\max (i)}$ is its pressure value at the temperature of extraction $\left(T_{e}\right)$.

These plots are very useful because they immediately identify the main products of the thermal decomposition during the carbonization process. Therefore, any similarities and differences in behavior between the coals during pyrolysis can be put clearly in evidence. The symmetric emission of many components, as appears in Figures 8(a), 8(b), 9(a), and 9(b), can be explained as follows: by increasing the temperature, the rate of pyrolysis in the macrostructures increases, with a consequent decrease of the functional groups from which the products originated. In this context, it is possible to note that South Africa coal presents a maximum value of gas emission at about $600^{\circ} \mathrm{C}$, while Sulcis coal shows a maximum at around $400^{\circ} \mathrm{C}$, releasing acetone and isobutene. This is in agreement with spectral changes observed for their residuals obtained in the previous investigation [35].

At $300^{\circ} \mathrm{C}, \mathrm{SO}_{2}$ emission coming from Sulcis coal is at its maximum, while this component only appears in traces in the other coal. By comparing $\mathrm{CO}_{2}$ production of both coals, it is possible to note that this component is also predominant in the case of Sulcis coal, rather than in the South African one, according to the low rank of carbonization of the Italian coal. In fact, it contains a great number of unities having oxygen, so its infrared spectrum is similar to the one of a pit coal. By increasing the temperature, the release of $\mathrm{CO}_{2}$ increases, in agreement with the greater energy required to break these unities.

Some components, such as acetone and hydrocyanic acid, do not present a symmetric emission with temperature because they have a different origin. In particular, for the production of $\mathrm{HCN}$, a first emission at $400^{\circ} \mathrm{C}$ for Sulcis coal and at $500^{\circ} \mathrm{C}$ for the African one was observed. For Sulcis coal, the presence of functional amide groups $\left(\mathrm{R}-\mathrm{CO}-\mathrm{NH}_{2}\right)$ allows the production of $\mathrm{HCN}$ by a dehydration reaction [54]:

$$
\mathrm{H}-\mathrm{CO}-\mathrm{NH}_{2} \longrightarrow \mathrm{HCN}+\mathrm{H}_{2} \mathrm{O} \text {. }
$$

This reaction occurs at about $400^{\circ} \mathrm{C}$ in the presence of components as alumina, clay, and zinc oxide, and these materials are not difficult to to be found in coals.

\section{Conclusion}

The investigated coals contain gaseous components trapped into the interstices of the coal matrix, as shown by infrared spectra of the gases collected at room temperature and at $100^{\circ} \mathrm{C}$.

The FT-IR spectroscopy is a powerful technique for investigation of coal pyrolysis, since it allows to distinguish the compositions of Sulcis and South Africa coals. The thermal treatment of these coals involves a first-stage pyrolysis in which structural changes and decomposition of functional organic groups occur, with the formation of tar, and generation of vapors and gases. From about $400^{\circ} \mathrm{C}$, a second pyrolysis process takes place proceeding with the thermal cracking of tar, skeleton framework, reactions in the pores between the coal matrix and gases, dehydration of the minerals and changes in surface areas. The quantity of these gases is higher for Sulcis coal, according to its rank and the elemental and proximate analyses. Plots of pressures $P_{r(i)}=$ $P_{(i)}\left(T_{r}\right) / P_{\max (i)}\left(T_{e}\right)$ against temperature show the correlation among qualitative gas composition, temperature, and the maximum value of emission. These plots are very useful because they uniquely identify the main products of the thermal decomposition during the carbonization process. Furthermore, these data could be integrated in structural models for coal pyrolysis to evaluate pyrolysis kinetics.

\section{References}

[1] K. Miura, "Mild conversion of coal for producing valuable chemicals," Fuel Processing Technology, vol. 62, no. 2, pp. 119135, 2000.

[2] B. Avid, B. Purevsuren, M. Born, J. Dugarjav, Y. Davaajav, and A. Tuvshinjargal, "Pyrolysis and TG analysis of Shivee Ovoo coal from Mongolia," Journal of Thermal Analysis and Calorimetry, vol. 68 , no. 3, pp. 877-885, 2002.

[3] J. W. Patrick, A. Walker, and S. Hanson, "The effect of coal particle size on pyrolysis and steam gasification," Fuel, vol. 81, no. 5, pp. 531-537, 2002.

[4] L. Yang, J. Ran, and L. Zhang, "Mechanism and kinetics of pyrolysis of coal with high ash and low fixed carbon contents," Journal of Energy Resources Technology, vol. 133, no. 3, Article ID 031701, pp. 1-7, 2011.

[5] R. W. Niemeier, "Petroleum, coal tar, and related products," in Patty's Toxicology, pp. 325-370, John Wiley \& Sons, New York, NY, USA, 2012.

[6] L. S. Pedersen, H. P. Nielsen, S. Kiil et al., "Full-scale co-firing of straw and coal," Fuel, vol. 75, no. 13, pp. 1584-1590, 1996.

[7] C. Meesri and B. Moghtaderi, "Lack of synergetic effects in the pyrolytic characteristics of woody biomass/coal blends under low and high heating rate regimes," Biomass and Bioenergy, vol. 23, no. 1, pp. 55-66, 2002.

[8] H. Haykiri-Acma and S. Yaman, "Interaction between biomass and different rank coals during co-pyrolysis," Renewable Energy, vol. 35, no. 1, pp. 288-292, 2010.

[9] C. A. Ulloa, A. L. Gordon, and X. A. García, "Thermogravimetric study of interactions in the pyrolysis of blends of coal with radiata pine sawdust," Fuel Processing Technology, vol. 90, no. 4, pp. 583-590, 2009.

[10] C.-Z. Li, K. D. Bartle, and R. Kandiyoti, "Vacuum pyrolysis of maceral concentrates in a wire-mesh reactor," Fuel, vol. 72, no. 11, pp. 1459-1468, 1993.

[11] L. Zhang, S. Xu, W. Zhao, and S. Liu, "Co-pyrolysis of biomass and coal in a free fall reactor," Fuel, vol. 86, no. 3, pp. 353-359, 2007.

[12] D.-M. He, L. Zhang, J. Guan, and Q. M. Zhang, "The comparative study of Honghe lignite pyrolysis under the atmosphere of methanol and nitrogen," Advanced Materials Research, vol. 512515, pp. 1784-1789, 2012. 
[13] D. M. P. Wu and D. P. Harrison, "Volatile products from lignite pyrolysis and hydropyrolysis," Fuel, vol. 65, no. 6, pp. 747-751, 1986.

[14] J. B. Howard, "Fundamentals of coal pyrolysis and hydropyrolysis," in Chemistry of Coal Utilization Secondary Supplementary Volume, pp. 665-784, John Wiley \& Sons, New York, NY, USA, 1981.

[15] N. Qiu, H. Li, E. Xu, J. Qin, and L. Zheng, "Temperature and time effects on free radical concentration in organic matter: evidence from laboratory pyrolysis experimental and geological samples," Energy Exploration and Exploitation, vol. 30, no. 2, pp. 311-330, 2012.

[16] R. D. Srivastava, H. G. Mcllvried III, and J. C. Winslow, "Coal technology for power, liquid fuels, and chemicals," in Kent and Riegel's Handbook of Industrial Chemistry and Biotechnology, chapter 19, pp. 843-906, Springer Science + Business Media, New York, NY, USA, 11th edition, 2007.

[17] J. Rezaiyan and N. P. Cheremisinoff, "Pyrolysis," in Gasification Technologies: A Primer for Engineers and Scientists, pp. 145-164, CRC, New York, NY, USA; Taylor \& Francis, Boca Raton, Fla, USA, 2005.

[18] L. Tognotti, G. Bertozzi, L. Petarca, A. D’Alessio, and E. Benedetti, "Low-temperature oxidation of a bituminous coal: its structural implications," La Chimica e L'Industria, vol. 70, no. 9, pp. 76-80, 1988.

[19] L. Tognotti, L. Petarca, A. D’Alessio, and E. Benedetti, "Low temperature air oxidation of coal and its pyridine extraction products. Fourier transform infrared studies," Fuel, vol. 70, no. 9, pp. 1059-1067, 1991.

[20] A. D’Alessio and E. Benedetti, "Infrared analysis of the structural changes of Sulcis and other coals under progressive heating," La Chimica e L'Industria, vol. 66, pp. 689-693, 1984.

[21] A. Karcz and S. Porada, "The influence of coal rank on formation of gaseous hydrocarbons in hydrogasif ication of coal," Fuel, vol. 75, no. 5, pp. 641-645, 1996.

[22] K. Murakami, H. Shirato, and Y. Nishiyama, "In situ infrared spectroscopic study of the effects of exchanged cations on thermal decomposition of a brown coal," Fuel, vol. 76, no. 7, pp. 655-661, 1997.

[23] B. J. Meldrum and C. H. Rochester, "Infrared spectra of carbonaceous chars under carbonization and oxidation conditions," Fuel, vol. 70, no. 1, pp. 57-63, 1991.

[24] J. B. Ibarra, R. Moliner, and A. J. Bonet, "FT-i.r. investigation on char formation during the early stages of coal pyrolysis," Fuel, vol. 73, no. 6, pp. 918-924, 1994.

[25] P. Keliang, X. Wenguo, and Z. Changsui, "Investigation on pyrolysis characteristic of natural coke using thermogravimetric and Fourier-transform infrared method," Journal of Analytical and Applied Pyrolysis, vol. 80, no. 1, pp. 77-84, 2007.

[26] S. S. Idris, N. A. Rahman, K. Ismail, A. B. Alias, Z. A. Rashid, and M. J. Aris, "Investigation on thermochemical behaviour of low rank Malaysian coal, oil palm biomass and their blends during pyrolysis via thermogravimetric analysis (TGA)," Bioresource Technology, vol. 101, no. 12, pp. 4584-4592, 2010.

[27] R. M. Carangelo, P. R. Solomon, and D. J. Gerson, "Application of TG-FT-IR to study hydrocarbon structure and kinetics," Fuel, vol. 66, no. 7, pp. 960-967, 1987.

[28] P. R. Solomon, M. A. Serio, and E. M. Suuberg, "Coal pyrolysis: experiments, kinetic rates and mechanisms," Progress in Energy and Combustion Science, vol. 18, no. 2, pp. 133-220, 1992.
[29] I. Pitkänen, J. Huttunen, H. Halttunen, and R. Vesterinen, "Evolved gas analysis of some solid fuels by TG-FTIR," Journal of Thermal Analysis and Calorimetry, vol. 56, no. 3, pp. 1253$1259,1999$.

[30] E. Ekinci, F. Yardim, M. Razvigorova et al., "Characterization of liquid products from pyrolysis of subbituminous coals," Fuel Processing Technology, vol. 77-78, pp. 309-315, 2002.

[31] L. Bonfanti, L. Comellas, J. L. Lliberia, R. Vallhonrat-Matalonga, M. Pich-Santacana, and D. López-Piñol, "Pyrolysis gas chromatography of some coals by nitrogen and phosphorus, flame ionisation and mass spectrometer detectors," Journal of Analytical and Applied Pyrolysis, vol. 44, no. 1, pp. 101-119, 1997.

[32] D. Fabbri, I. Vassura, and C. E. Snape, "Simple off-line flash pyrolysis procedure with in situ silylation for the analysis of hydroxybenzenes in humic acids and coals," Journal of Chromatography A, vol. 967, no. 2, pp. 235-242, 2002.

[33] G. Gryglewicz, P. Rutkowski, and J. Yperman, "Characterization of sulfur compounds in supercritical coal extracts by gas chromatography-mass spectrometry," Fuel Processing Technology, vol. 77-78, pp. 167-172, 2002.

[34] Q. yang, S. Wu, R. Lou, and G. Lv, "Analysis of wheat straw lignin by thermogravimetry and pyrolysis-gas chromatography/mass spectrometry," Journal of Analytical and Applied Pyrolysis, vol. 87, no. 1, pp. 65-69, 2010.

[35] A. D’Alessio, P. Vergamini, and E. Benedetti, "FT-IR investigation of the structural changes of Sulcis and South Africa coals under progressive heating in vacuum," Fuel, vol. 79, no. 10, pp. 1215-1220, 2000.

[36] R. H. Perry and C. H. Chilton, Chemical Engineers Handbook, Mc Graw-Hill, New York, NY, USA, 8th edition, 2007.

[37] D. N. Kendall, Applied Infrared Spectroscopy, Reinhold, New York, NY, USA, 1966.

[38] M. V. Zeller, Infrared Methods in Air Analysis, Perkin-Elmer Corporation, Eden Prairie, Minn, USA, 2000.

[39] E. B. Ledesma, C. Li, P. F. Nelson, and J. C. Mackie, "Release of $\mathrm{HCN}, \mathrm{NH}_{3}$, and $\mathrm{HNCO}$ from the thermal gas-phase cracking of coal pyrolysis tars," Energy and Fuels, vol. 12, no. 3, pp. 536-541, 1998.

[40] L. L. Tan and C. Li, "Formation of $\mathrm{NO}_{x}$ and $\mathrm{SO}_{x}$ precursors during the pyrolysis of coal and biomass. Part I. Effects of reactor configuration on the determined yields of $\mathrm{HCN}$ and $\mathrm{NH}_{3}$ during pyrolysis," Fuel, vol. 79, no. 15, pp. 1883-1889, 2000.

[41] R. Bassilakis, Y. Zhao, P. R. Solomon, and M. A. Serio, "Sulfur and nitrogen evolution in the Argonne coals: experiment and modeling," Energy \& Fuels, vol. 7, no. 6, pp. 710-720, 1993.

[42] T. Maffei, S. Sommariva, E. Ranzi, and T. Faravelli, "A predictive kinetic model of sulfur release from coal," Fuel, vol. 91, no. 1, pp. 213-223, 2012.

[43] J. Yan, J. Yang, and Z. Liu, "SH radical: the key intermediate in sulfur transformation during thermal processing of coal," Environmental Science and Technology, vol. 39, no. 13, pp. 50435051, 2005.

[44] K. Miura, K. Mae, M. Shimada, and H. Minami, "Analysis of formation rates of sulphur-containing gases during the pyrolysis of various coals," Energy and Fuels, vol. 15, no. 3, pp. 629-636, 2001.

[45] P. Selsbo, P. Almén, and I. Ericsson, "Quantitative analysis of sulfur in coal by pyrolysis-gas chromatography and multivariate data analysis," Energy and Fuels, vol. 10, no. 3, pp. 751-756, 1996.

[46] L. Duan, C. Zhao, W. Zhou, C. Liang, and X. Chen, "Sulfur evolution from coal combustion in $\mathrm{O}_{2} / \mathrm{CO}_{2}$ mixture," Journal 
of Analytical and Applied Pyrolysis, vol. 86, no. 2, pp. 269-273, 2009.

[47] G. L. Hu, K. Dam, S. Wedel, and J. P. Hansen, "Decomposition and oxidation of pyrite," Progress in Energy and Combustion Science, vol. 32, no. 3, pp. 295-314, 2006.

[48] P. J. Cleyle, W. F. Caley, L. Stewart, and S. G. whiteway, "Decomposition of pyrite and trapping of sulphur in a coal matrix during pyrolysis of coal," Fuel, vol. 63, no. 11, pp. 15791582, 1984.

[49] M. R. Khan and T. Kurata, "The feasibility of mild gasification of coal: research needs," 1985, DOE/METC-85/4019, NTIS/DE85013625.

[50] S. Furfari and R. Cyprès, "Hydropyrolysis of a high-sulphurhigh-calcite Italian Sulcis coal. 2. Importance of the mineral matter on the sulphur behaviour," Fuel, vol. 61, no. 5, pp. 453459, 1982.

[51] D. Shao, E. J. Hutchinson, J. Heidbrink, W. Pan, and C. Chou, "Behavior of sulfur during coal pyrolysis," Journal of Analytical and Applied Pyrolysis, vol. 30, no. 1, pp. 91-100, 1994.

[52] J. J. Pitt, "Structure analysis of coal," in Coal and Modern Coal processing: An Introduction, pp. 27-50, Academic Press, London, UK, 1979.

[53] C. Poucher, The Aldrich Library of FT-IR Spectra, John Wiley \& Sons, New York, NY, USA, 1997.

[54] V. S. Nguyen, H. L. Abbott, M. M. Dawley, T. M. Orlando, J. Leszczynski, and M. T. Nguyen, "Theoretical study of formamide decomposition pathways," Journal of Physical Chemistry $A$, vol. 115, no. 5, pp. 841-851, 2011. 

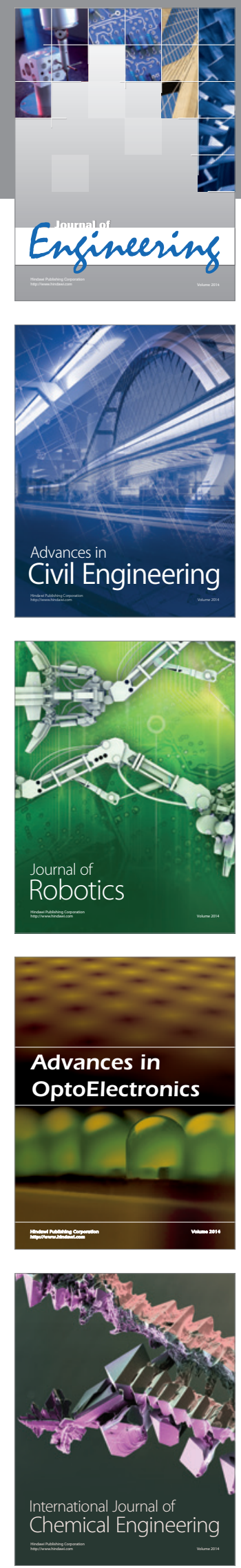

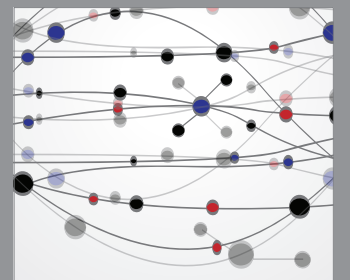

The Scientific World Journal
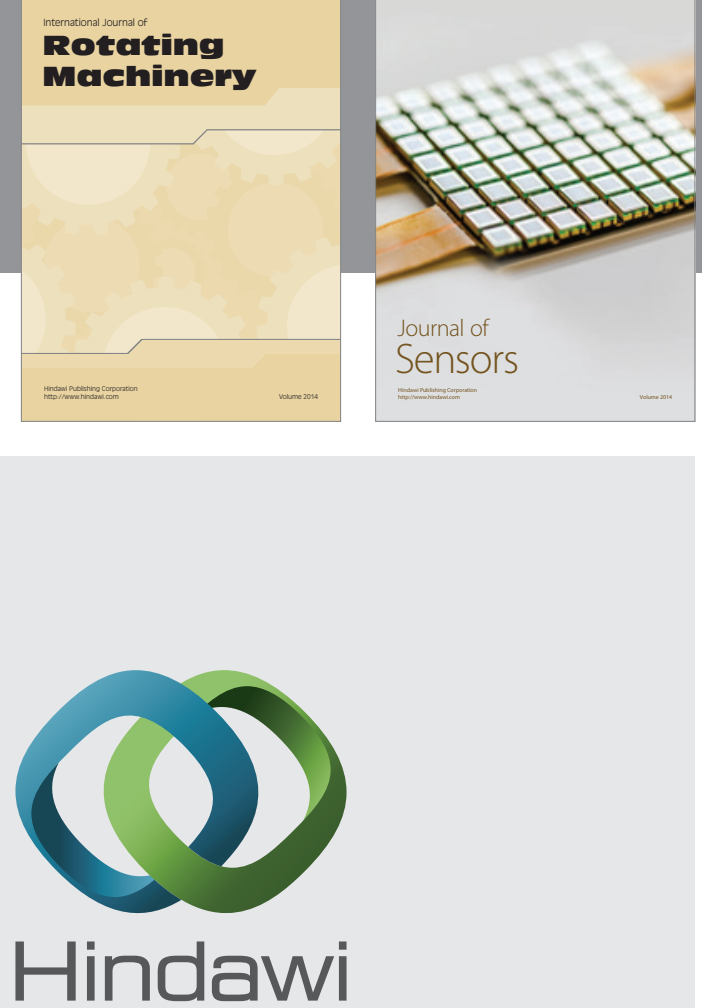

Submit your manuscripts at http://www.hindawi.com
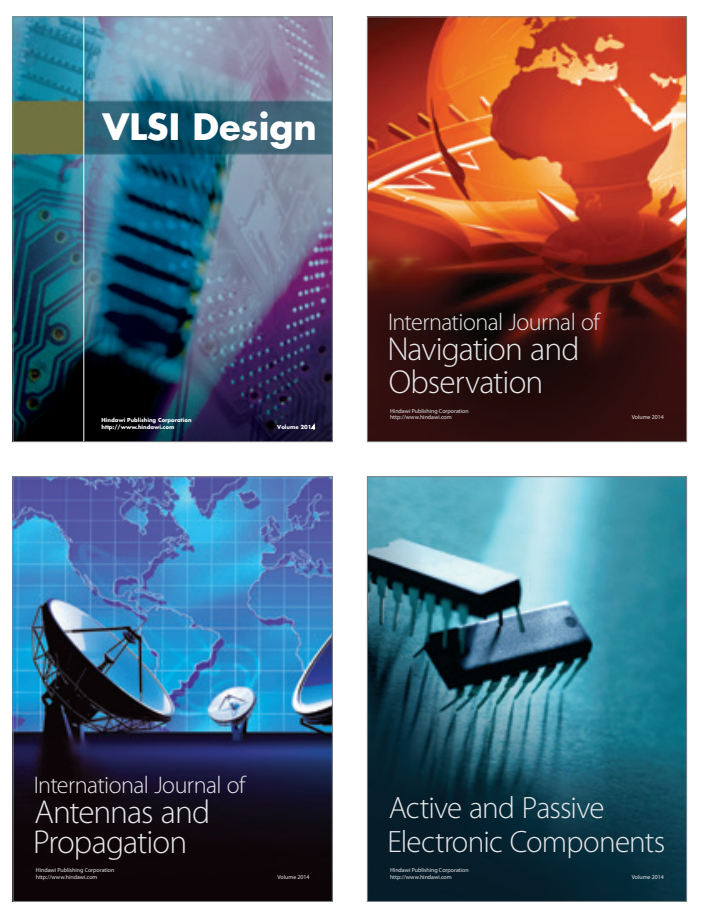
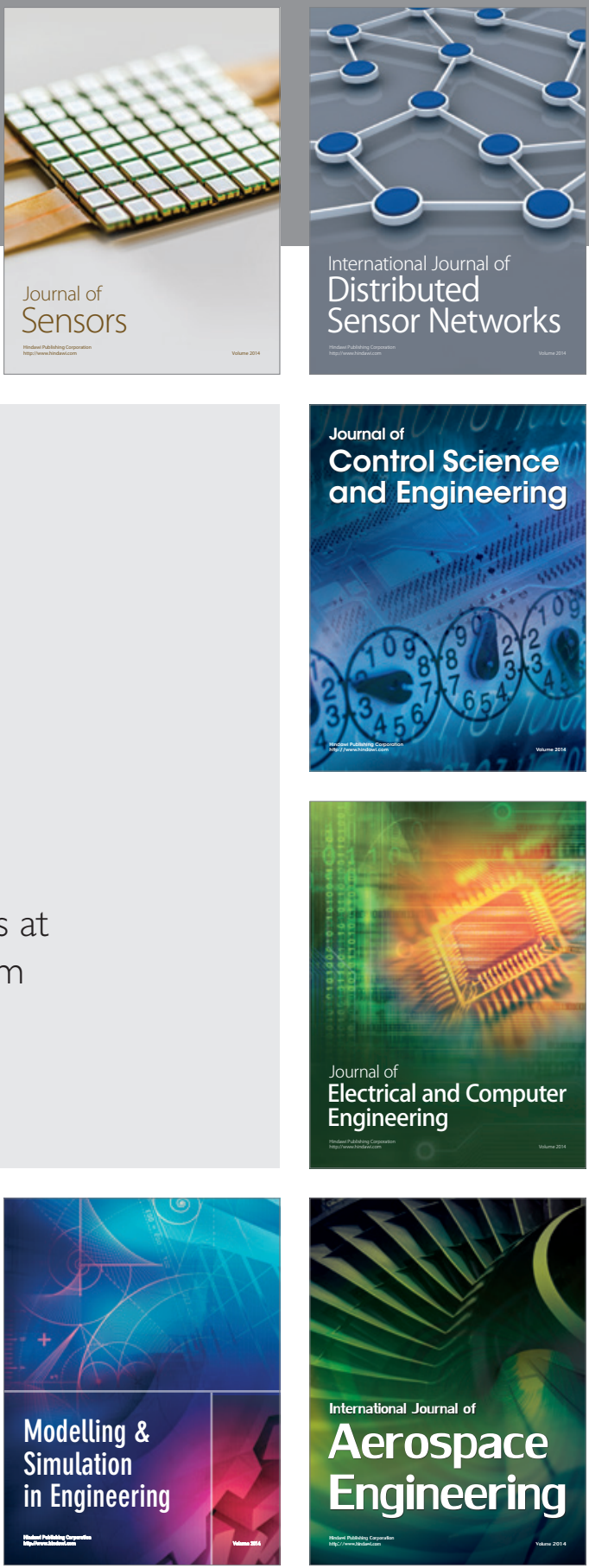

Journal of

Control Science

and Engineering
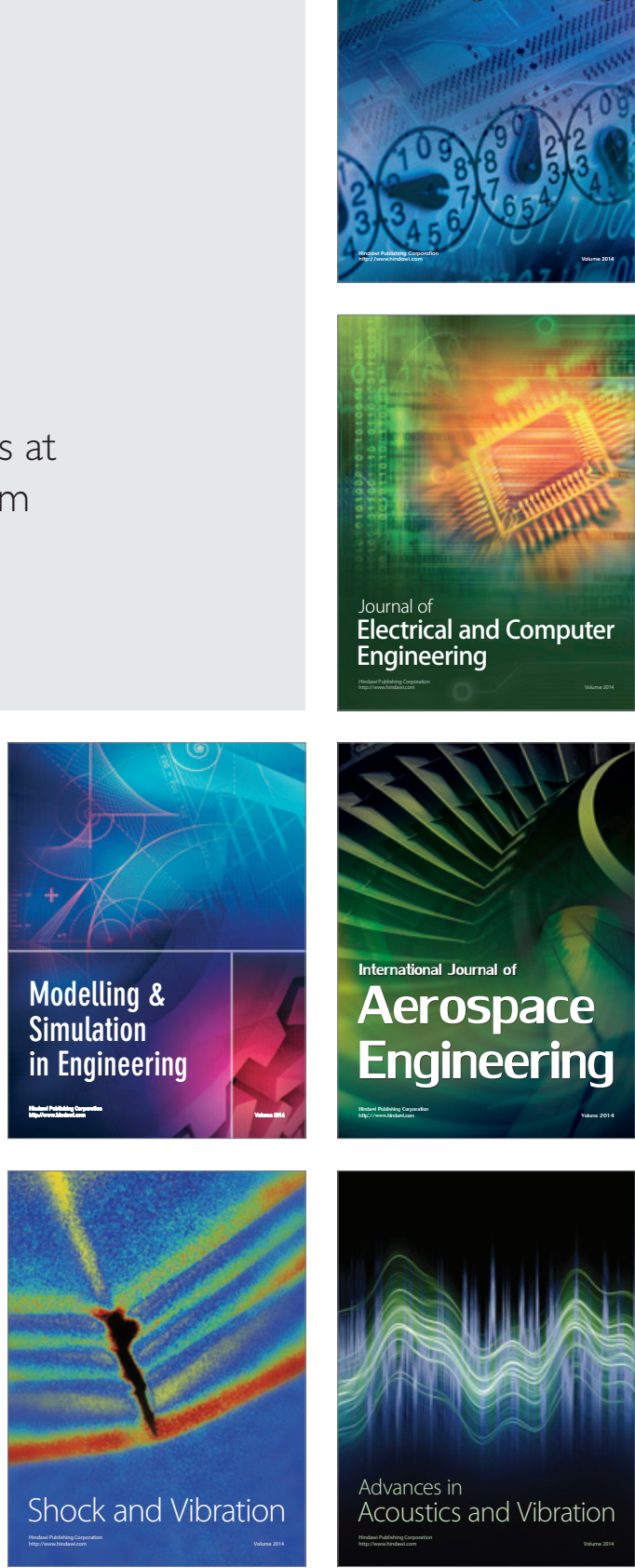